This item was submitted to Loughborough's Research Repository by the author.

Items in Figshare are protected by copyright, with all rights reserved, unless otherwise indicated.

\title{
Middle Holocene marine flooding and human response in the south Yangtze coastal plain, East China
}

PLEASE CITE THE PUBLISHED VERSION

https://doi.org/10.1016/j.quascirev.2018.03.001

\section{PUBLISHER}

(C) Elsevier

\section{VERSION}

AM (Accepted Manuscript)

\section{PUBLISHER STATEMENT}

This work is made available according to the conditions of the Creative Commons Attribution-NonCommercialNoDerivatives 4.0 International (CC BY-NC-ND 4.0) licence. Full details of this licence are available at: https://creativecommons.org/licenses/by-nc-nd/4.0/

\section{LICENCE}

CC BY-NC-ND 4.0

\section{REPOSITORY RECORD}

Wang, Zhanghua, David Ryves, Shao Lei, Xiaomei Nian, Ye Lv, Liang Tang, Long Wang, Jiehua Wang, and Jie [Shanghai Museum] Chen. 2018. "Middle Holocene Marine Flooding and Human Response in the South Yangtze Coastal Plain, East China”. Loughborough University. https://hdl.handle.net/2134/32549. 
1 Middle Holocene marine flooding and human response in the south Yangtze

3 Zhanghua Wang ${ }^{1 *}$, David coastal plain, East China China.

Long Wang ${ }^{1}$, Jiehua Wang ${ }^{3}$, Jie Chen ${ }^{4}$

${ }^{1}$ State Key Laboratory of Estuarine and Coastal Research, East China Normal University, Shanghai 200062, China.

${ }^{2}$ Centre for Hydrological and Ecosystem Science (CHES), Department of Geography, Loughborough University, Loughborough LE11 3TU, UK.

${ }^{3}$ Ningbo Municipal Institute of Cultural Relics and Archaeology, Ningbo 315000,

${ }^{4}$ Shanghai Museum, Shanghai 200003, China

*Corresponding author: zhwang@geo.ecnu.edu.cn

Abstract: Coastal flooding catastrophes have affected human societies on coastal plains around the world on several occasions in the past, and are threatening $21^{\text {th }}$ century societies under global warming and sea-level rise. However, the role of coastal flooding in the interruption of the Neolithic Liangzhu culture in the lower Yangtze valley, East China coast has been long contested. In this study, we used a well-dated Neolithic site (the Yushan site) close to the present coastline to demonstrate a marine drowning event at the terminal stage of the Liangzhu culture and discuss its linkage to relative sea-level rise. We analysed sedimentology, chronology, organic elemental composition, diatoms and dinoflagellate cysts for 
several typical profiles at the Yushan site. The field and sedimentary data provided clear evidence of a palaeo-typhoon event that overwhelmed the Yushan site at 2560 $\mathrm{BCE}$, which heralded a period of marine inundation and ecological deterioration at the site. We also infer an acceleration in sea-level rise at 2560-2440 BCE from the sedimentary records at Yushan, which explains the widespread signatures of coastal flooding across the south Yangtze coastal plain at that time. The timing of this midHolocene coastal flooding coincided with the sudden disappearance of the advanced and widespread Liangzhu culture along the lower Yangtze valley. We infer that extreme events and flooding accompanying accelerated sea-level rise were major causes of vulnerability for prehistoric coastal societies.

Keywords: Palaeo-typhoon event; Sea-level rise; Coastal flooding; Neolithic

\section{Introduction}

Global sea-level rise is predicted to accelerate during the $21^{\text {st }}$ century and could rise $65 \pm 12 \mathrm{~cm}$ by 2100 compared with 2005 (Kopp et al., 2016; Nerem et al., 2018), which will increase the frequency of extreme events and the risk of coastal flooding (Woodruff et al., 2013). The vulnerability of low-lying coastal plains and deltas across the world is further exacerbated due to human-induced sediment starvation and land sinking (Syvitski et al., 2009; Giosan et al., 2014). The west Pacific Ocean coast is one of the most vulnerable regions in the world because it is characterized by active tropical cyclones (Woodruff et al., 2013) and, in recent decades, its rate of relative sea-level rise is three times higher than the global mean (Nicholls and Cazenave, 
2010). In the densely-populated Yangtze delta, East China (Fig. 1), models under future climate scenarios predict an increase in flood risk from extreme events and relative sea-level rise by $150 \%$ to $400 \%$ in the next 50 years (Tessler et al., 2015). In fact, Typhoon Fitow (the strongest October typhoon making landfall in China for over 60 years) in 2013 caused flooding to a depth $>0.5 \mathrm{~m}$ across most of the Yaojiang Plain, south east of the Hangzhou Bay (Fig. 1C). There is thus clearly an urgent need for integrated research on sea-level rise, extreme events, coastal flooding and human response.

Coastal flooding is not a new threat. The fact that the south Yangtze coastal plains (Fig. 1B) hold relative thick and rich archaeological records, preserved in marine and deltaic flood basin sediments (Zong et al., 2007; Zheng et al., 2012), is direct witness of past flooding of these areas during human occupation. Neolithic people including the well-known Kuahuqiao, Hemudu and Liangzhu cultures settled and practiced flood management on the coastal wetlands of Hangzhou Bay (Fig. 1) since $\sim 6000$ BCE (Zhao, 1998; Zong et al., 2007; Liu and Chen, 2012; Qin, 2013; Liu et al., 2017). People of the Liangzhu culture, which was one of the most developed and complex societies known in prehistory (Lawler, 2009; Liu and Chen, 2012; Qin, 2013), even constructed massive earth-and-stone walls to hold back floods near their capital city, Mojiaoshan, at the head of Hangzhou Bay near present-day Hangzhou (Fig. 1B; Lawler, 2009; Liu and Chen, 2012; Liu et al., 2017). Yet they abandoned their state capital complex at around $2500 \mathrm{BCE}$, as shown by dating sedimentary profiles from the capital city (Zhang et al., 2015; Wang et al., 2017), despite their 
highly developed techniques in agricultural and landscape management (Zhuang et al., 2014; Liu et al., 2017). The subsequent Neolithic Qianshanyang and Guangfulin cultures that appeared at $\sim 2400-1800$ BCE were reported to be much less organized and less developed (Shanghai Museum, 2002; ZPICRA and Huzhou Museum, 2014). Studying these archaeological records with a focus on the linkage between flood deposits and cultural interruptions can shed light on the increasing flood risk in this economically important and populous area in the near future.

There has been much speculation and debate surrounding the Liangzhu cultural decline among archaeologists and environmental scientists. Archaeologists speculate that the abandonment of the Liangzhu capital city might have been related to floods because a layer of silt, inferred as flood deposits, was found on top of the late Liangzhu cultural layer in many areas around the capital city (Liu and Chen, 2012). An early environmental study suggested marine inundation played a key role, based on the marine fossil record of core ZX-1 in the eastern Taihu Plain (Stanley et al., 1999), but later work reported no marine flooding at other sites in the Taihu Plain at this time (Zong et al., 2011). Later Innes et al. (2014) suggested a combination of rising local water level and climatic deterioration was the probable cause. We propose that to settle the debate and test these competing hypotheses, it is necessary to carry out an integrated study of relative sea-level change and environmental and human response. It is particularly important to examine directly the event-character of the floodbeds covering the Liangzhu culture layer recovered from archaeological sites. 

the present coastline (Figs 1, 2A). Diagnostic black pottery and tools for woodworking and farming (Fig. 1D-F) of the Liangzhu culture were recovered from this site. The Liangzhu cultural layer was overlain by mud deposits $\sim 0.4-0.5 \mathrm{~m}$ thick which did not contain artefacts, hinting at an inundation event at the end of the Liangzhu culture. Yushan may therefore be key to addressing this debate based on a prehistorical human societies to extreme events and flooding.

\section{The study area and the site}



plains along the Hangzhou Bay, including the Yaojiang Plain, which is located to the south east and is separated by uplands from Hangzhou Bay (Fig. 1B). Sediments deposited in these plains were derived mainly from the Yangtze River during the Holocene, as sediment load from other local rivers is negligible compared to that from the Yangtze River (Liu et al., 2013). The freshwater-dominated Taihu Plain was

116 formed $\sim 6500-6000$ years ago when sea level was relatively stable and the Yangtze 117 delta started its progradation (Hori et al., 2001; Wang et al., 2012). However, the rate 118 of shoreline advance was extremely slow between 6500 and 4000 years ago, as 119 indicated by distribution of the chenier ridges in the east part of the plain (Fig. 1B;

120 Yan et al., 1989), caused mainly by a large amount of sediment trapping in the north 121 Yangtze delta plain (Li et al., 2002; Hori et al., 2001) and the decline in the Yangtze sediment supply owing to weakening of the East Asian Summer Monsoon 6000 years ago (Zhan et al., 2012). Rapid shoreline accretion only occurred over past 2000 124 years, in concert with an increase in sediment supply from human activity (Hori et al., 2001; Wang et al., 2011). Sediment cores from the south coastal plain of Hangzhou

126 Bay demonstrate that rapid infilling of Hangzhou Bay occurred during the early

127 Holocene (Gao and Collins, 2014; Zhang et al., 2015). A long period of sedimentary 128 hiatus then occurred during the middle to late Holocene with return to net sedimentation in Hangzhou Bay only in the past 2000 years (Gao and Collins, 2014; 
et al., 1985). The Yaojiang Plain of south east Hangzhou Bay has a smaller mean tidal range of $1.85 \mathrm{~m}$. Uehara et al. (2002) reconstructed the palaeotidal fields in the Yangtze Estuary and the east China marginal sea by including the effect of palaeotopographic change from sedimentation since the Last Glacial Maximum. The simulated amplitude $\mathrm{M}_{2}$ tide, which is the most significant component of tide in this region, was 1.0-1.2 $\mathrm{m}$ on the coast south to the Hangzhou Bay (including the Yaojiang Plain) and 1.2-1.4 m on the coast of Taihu Plain during the middle Holocene (6 ka; Uehara et al., 2002). It has increased to $1.2-1.6 \mathrm{~m}$ in the inner and south part of the Hangzhou Bay at the present day, while remaining at $1.0-1.2 \mathrm{~m}$ in the south east part of the Bay. Ground elevation is $0-2 \mathrm{~m}$ above present mean sea level (the Yellow Sea datum, MSL $_{Y S D}$ ) in most of central Taihu Plain and Yaojiang Plain, and 2-5 $\mathrm{m}$ in the plains along Hangzhou Bay (Fig. 1B).

The Yushan site is located in the north east of Yaojiang Plain, between the edge of the upland and the floodplain (Fig. 1). The site was excavated by the Ningbo Municipal Institute of Cultural Relics and Archaeology over an area of $4300 \mathrm{~m}^{2}$ during September, 2014 to January, 2015. Each excavation unit is $10 \mathrm{~m} \times 10 \mathrm{~m}$ in size (Fig. 2A). The archaeological sequence spans from the early/middle Hemudu culture to the Song dynasty, with ten layers numbered top to bottom correlating to distinct lithology, sedimentology and archaeological finds across the site (Table 1). Individual cultural layers are typically $25-50 \mathrm{~cm}$ thick, with the whole sequence spanning $1-2.5$ 
$\mathrm{m}$ across the site (Fig. 2B, C). The cultural layers onlap the weathered bedrock or hardened mud surfaces in excavation units close to the upland, such as T0410 and T0513. The Holocene base then dips rapidly and is buried below the floodplain (Fig. 2).

Among the 10 layers (Table 1), layers 9, 7,6 and 3 are composed of organic-rich mud or peat that contain artefacts of prehistoric early and middle Hemudu, late Hemudu and Liangzhu cultures and from the Shang and Zhou dynasty, respectively. Layers $10,8,5$ and 4 are devoid of any cultural artefacts and are considered to be formed without human disturbance. Note that layer 7 only occurs at the edge of the upland, such as in unit T0410 (Fig. 2C). In addition, an erosional surface is prominent on top of the peat layer 6a in many units, and this peat layer is totally eroded away even in those units close to the upland (Figs 2,3). Together with the erosional surface, a sand ridge of $20-30 \mathrm{~cm}$ high and ca. $60 \mathrm{~cm}$ wide that was defined as layer $5 \mathrm{~b}$, dips from the edge of upland eastward and cuts into layer 6 (Fig. 3D-F). Gravels, fragments of Liangzhu artefacts and abundant plant fragments were present in the sand ridge. Mixtures of sand and mud, also defined as layer $5 \mathrm{~b}$, only occurs above the erosional surface in the area between the sand ridge and the upland.

\section{Materials and Methods}

During our excavation, we carefully examined the lithological and stratigraphic sequences in each excavation unit. We selected the north wall of unit T0415 for 
analyses of proxies including organic chemistry, diatoms and dinoflagellate cysts, because this unit is on the east edge of the excavation area where less human disturbance occurred (Fig. 2A). We also collected samples for these proxy analyses from unit T0410 because layer 7 is missing in unit T0415. We then identified the sedimentary facies of each layer and recognized marine inundation by examining the lithology and analysing proxies.

Twenty-seven (27) samples were collected from the north wall of unit T0415 for analyses of organic carbon and diatoms. Thirty-four (34) samples from layer 3 to 9 from the west wall of unit T0410 and seven samples from layer 6 of unit T0415 were collected for dinoflagellate cyst identification. In addition, seven tree stumps collected from the top of peat layer 6 in units T0214, T0314, T0315 and T0415 were identified at species level at the Institute of Archaeology, Chinese Academy of Social Science. Samples for organic carbon measurement were dried at $40^{\circ} \mathrm{C}$ in an oven and milled to powder. Two aliquots were prepared for each sample: (1) $20 \mathrm{mg}$ powder was used to measure total carbon and total nitrogen $(\mathrm{TN})$ using a vario MAX cube $\mathrm{CN}$ analyser (Elementar, Germany) (error $<1 \%$ ) at the State Key Laboratory of Marine Geology, Tongji University, China; (2) about 0.5 g powder was mixed with $0.1 \mathrm{M}$ hydrochloric acid $(\mathrm{HCl})$ for 24 hours to remove carbonate and then washed with deionized water thoroughly until the $\mathrm{pH}$ was neutral. The neutral specimen was dried at $40^{\circ} \mathrm{C}$ and then used for measurement of TOC by vario MAX cube $\mathrm{CN}$ analyser (error $<1 \%$ ) at Tongji University and $\delta^{13} \mathrm{C}_{\mathrm{V}-\mathrm{PDB}} \%$ (error, $\pm 0.2 \%$; reference material: 
195

(Thermo Scientific, Germany) at the Third Institute of Oceanography, State Oceanic Administration of China. Samples for diatom analysis were prepared at Loughborough University in a water bath using $30 \% \mathrm{H}_{2} \mathrm{O}_{2}$ to remove organic matter and $\mathrm{HCl}$ to remove carbonates, following the procedure of Renberg (1990), and permanent slides counted on a Leica DME light microscope (numerical aperture = 1.4) under oil immersion and phase contrast at x1000 magnification. Samples for dinoflagellate cysts identification were treated following standard procedures of pollen analysis (Moore et al., 1990) and the species were counted using a Leica optical microscope at x400 magnification. The identification of dinoflagellate cysts was made according to regional taxonomic guides (He et al., 2009; Mao et al., 2011; Tang et al., 2013).

For building the chronology, eight samples of charcoal, plant fragment and organic sediment from units T0410 and T0513 were AMS ${ }^{14} \mathrm{C}$ dated by Beta Analytic, USA, and calibrated using the Calib 7.1 program (Stuiver et al., 2015; Table 2). Furthermore, a sample from the sand ridge above the peat layer in T0513 (Fig. 3E) was dated using single-grain optically stimulated luminescence (OSL) measurement of quartz (Duller, 2008). In total, 3500 grains of quartz (180-224 $\mu \mathrm{m})$ were measured and 37 grains were accepted for age determination (Table 3; Fig. S1). Luminescence measurements were carried out by an automated Risø-TL/OSL DA-20 DASH reader equipped with a ${ }^{90} \mathrm{Sr} /{ }^{90} \mathrm{Y}$ beta source (Bøtter-Jensen et al., 2003) and an ET EMD9107 photomultiplier tube at the State Key Laboratory of Estuarine and Coastal Research, East China Normal University. 
We also decided to use the south excavation wall of unit T0513 and west wall of unit T0410 for relative sea level reconstruction. In the south wall of unit T0513, the

Holocene base of hardened mud dips gradually from west to east while peaty mud layer 9 and peat layer 6a formed the basal peat from east to west, respectively (Fig. 2B). In the west wall of unit T0410, as the thick layer of peat (layer 6) was eroded away and the sedimentary sequence above the Holocene base is only $\sim 150 \mathrm{~cm}$ thick in the north part (Fig. 2C), sediment compaction can be neglected when applying the sea-level indicators from this profile. When collecting the radiocarbon dating material, three sample from layers 9,8 and 6 in unit T0513, and three samples from layers 7, 4 and 3 in unit T0410 were chosen for reconstruction of relative sea levels 
In addition, we collected and recalibrated 80 published radiocarbon ages (Table

240 S1) during and after the Liangzhu culture from Neolithic sites across the East China coastal plain using the Calib 7.1 programme (Stuiver et al., 2015) to revise the time span of the Liangzhu culture. We also compiled all published sedimentary profiles dated by AMS ${ }^{14} \mathrm{C}$ in the study area (Fig. S2 for their location) and compared the database covering the end of the Liangzhu culture which included radiocarbon ages

245 (also recalibrated; Table S2), ecological and environmental proxies, and signals of 246 flooding (Table 5).

\section{Results}

\subsection{Holocene stratigraphy and sedimentary environmental change at Yushan}

There is clear variation in organic geochemistry in each layer, distinguishing the terrestrial or marine source of organic carbon (Fig. 4). Diatom preservation is poor throughout much of the sequence, and identifiable valves were only observed in marine genera including Spiniferites, Operculodinium and Lingulodinium were found in the non-cultural layers of 8,5 and 4 and the bottom section of layer 3 . Below we

257 present the results of chronology, stratigraphic patterns of proxies and interpretation of sedimentary environments of layers 10-2. 
261

262

$\delta^{13} \mathrm{C}$ indicate that the dominant source of organic carbon was freshwater algae or freshwater particulate organic carbon (POC) (Fig. 4B; Lamb et al., 2006). A terrigenous environment is thus inferred for the Yushan site before the settlement of Hemudu people.

\section{Layer 9 (early to middle Hemudu culture). A charcoal sample from this peaty} mud layer was dated to $4440-4540$ BCE (median age 4490 BCE; Table 2), which is in agreement with the artefacts of early to middle Hemudu culture found in this layer. TOC increases to $\sim 5 \% ; \delta^{13} \mathrm{C}$ analyses indicate that the organic carbon was derived from terrestrial $\mathrm{C}_{3}$ plants and freshwater POC or algae (Fig. 4A, B). Diatoms are sparse in the bottom samples of this layer, consisting of robust, freshwater benthic forms. The middle sample in this section contained several whole cells of Amphora copulata, a benthic species more typical of higher conductivity freshwaters. The presence of whole cells suggests that the diatoms were growing in situ, rather than transported to the site, implying shallow water. Subsequent samples at the top of this layer 9 included taxa typical of somewhat fresher, low nutrient and lower $\mathrm{pH}$ waters, such as Eunotia and Pinnularia, along with some elongate Fragilaria. No marine dinoflagellate cysts was observed. A coastal freshwater marsh environment was identified during the early to middle Hemudu period.

Layer 8 (artefact-absent mud covering the early to mid-Hemudu cultural layer). A radiocarbon age of $4310 \mathrm{BCE}(4260-4360 \mathrm{BCE})$ was obtained from a sample of plant fragments in the bottom section of this layer. TOC decreases sharply $(<1 \%)$ and its isotopic composition demonstrates a terrestrial origin (Fig. 4B). However, a few 
valves of marine coastal taxa (such as Rhaphoneis) were encountered (Fig. 4A). Furthermore, of the four samples analysed, the uppermost sample had no marine dinoflagellate cysts, while concentrations for the other three were 332, 78 and 365 cysts $\mathrm{g}^{-1}$ dry weight (dw). An upper tidal flat environment was thus inferred at the site after the end of the middle Hemudu culture.

Layer 7 (late Hemudu culture). Radiocarbon dating of charcoal from this organicrich mud layer gives an age of $4020 \mathrm{BCE}$ (3945-4170 BCE; Table 2), supporting the finds of artefacts of late Hemudu culture found in this layer. Organic carbon was derived from freshwater algae or POC and some terrestrial $\mathrm{C}_{3}$ plants (Fig. 4B). Only two samples contained marine dinoflagellate cysts among five samples in layer 7 , with concentrations of 53 and 582 cysts $\mathrm{g}^{-1} \mathrm{dw}$. These data indicate a saltmarsh environment during the late Hemudu culture.

Layer 6 (Liangzhu culture). Radiocarbon ages from two samples from the bottom and upper section of this layer are $3570 \mathrm{BCE}(3515-3640 \mathrm{BCE})$ and $2760 \mathrm{BCE}$ (2635-2880 BCE), respectively (Table 2; Fig. 3A), which is consistent with the Liangzhu artefacts found in this layer. Rooted in situ at the top of this peat layer are many tree stumps at the edge of the excavation area (Fig. 3B, C), all of which have been identified as mature willow (Salix; $\sim 12-25 \mathrm{~cm}$ in diameter; $1-6$ trees per excavation unit of $100 \mathrm{~m}^{2}$ ). This shrub is typical of the natural Yangtze coastal freshwater marsh, a zone located above MSHW (Zong et al., 2007; 2011). Both TOC and TN increase steadily throughout layer 6 , reaching values of almost $21 \%$ (TOC) and $1 \%(\mathrm{TN})$. Values of $\delta^{13} \mathrm{C}$ of approximately $-28 \%$ and TOC/TN $>15$ imply that 
this $\mathrm{OC}$ was dominantly derived from terrestrial $\mathrm{C}_{3}$ plants. Furthermore, a diverse flora of diatoms typical of shallow, freshwater/slightly brackish conditions appeared, including species of Cymbella, Amphora, Gyrosigma, Nitzschia and Navicula. Higher up the sequence, taxa typical of more distinctly brackish conditions were also found, including Ctenophora pulchella, Rhopalodia gibba and Chaetoceros cysts, as well as more clearly freshwater and low alkalinity taxa (Eunotia, Pinnularia, Cocconeis), suggesting a mixture of shallow wetland, freshwater and coastal marine habitats in the vicinity of the site. No marine dinoflagellate cysts was found. A coastal freshwater marsh close to the MSHW is inferred during the Liangzhu culture.

\section{Layer $5 b$ (gravelly sand, sand or sand-mud mixture cutting into the Liangzhu} peat). The sedimentary composition of the sand ridge consisting of gravel, sand and fragments of the Liangzhu artefacts indicates strong hydrodynamic force during its formation. A radiocarbon age of $2760 \mathrm{BCE}$ was derived from the plant fragments within the sand ridge, being identical with that of the underlying peat (Table 2), reflecting reworking from the peat. This sand ridge cutting into the peat layer, together with the sedimentary architecture including the erosional surface and tree stumps at the top of the underlying peat layer, reflect strong erosion and sudden deposition during a major storm event. Previous studies has reported similar deposition facies and sequences during storm events, such as the development of chenier ridges on the tidal flat of the Yangtze coast (Yan et al., 1989). OSL dating of single quartz grains within the sand ridge yielded an age of $4.59 \pm 0.24 \mathrm{ka} \mathrm{BP}$ (with a central age of $2575 \mathrm{BCE}$; Table 3). 
which overlies the early to mid-Hemudu peat, layer 5a of homogenous mud overlays

the Liangzhu peat in many units. At the bottom of this layer, TOC also abruptly implying that this organic matter was derived from marine algae or marine POC (Fig. 4B). In the upper part of layer 5, TOC increases slightly and $\delta^{13} \mathrm{C}$ shifts to the freshwater algal or POC range, indicating a short period of desalinisation. Some valve fragments of marine plankton (such as large Coscinodiscus) were encountered in one sample. Concentration of marine dinoflagellate cysts were abundant $\left(\sim 700-1500 \mathrm{~g}^{-1}\right.$ bottom of this layer. TOC drops further and was dominated by marine POC or 
probably a marine planktonic species, was found in one sample. Concentration of marine dinoflagellate cysts is high $\left(500-1500 \mathrm{~g}^{-1} \mathrm{dw}\right)$. Together with the lithological feature of silt lamination, we suggest an upper tidal-flat environment during the formation period of layer 4 . age of charcoal is $1395-1500 \mathrm{BCE}$ at the bottom of this section, which together with artefacts of Shang to Song dynasties, provides firm evidence that these two layers were formed during the historical period. TOC/TN increased in layers 3 and 2, and $\mathrm{OC}$ is dominated by freshwater algae and the POC contains a signal of terrestrial $\mathrm{C}_{3}$ plants (Fig. 4B). There are some marine dinoflagellate cysts (476 cysts $\mathrm{g}^{-1} \mathrm{dw}$ ) in the base of layer 3, indicating a saltmarsh environment at the beginning of Shang dynasty and a freshwater environment thereafter.

From the results of these multiproxy analyses of organic carbon sources, marine microfossils and the occurrence of human cultural layers, we speculate that humans settled at the Yushan site during periods when coastal freshwater marsh or saltmarsh interrupted by two marine intrusion events, corresponding to the interruption of the Hemudu and termination of the Liangzhu culture during 4310-4020 BCE and 2575-

$3671450 \mathrm{BCE}$, respectively. Note that the later event was characterized by a major storm event at its beginning, a storm that was strong enough to erode away the peat layer and form a sand ridge. 


\subsection{Ages of the storm event and the terminal of Liangzhu culture}

The OSL dating of quartz grains gives a direct age of $2575 \pm 240 \mathrm{BCE}$ for the sand ridge. However, a narrower age span is necessary to discuss the linkage between coastal flooding and the Neolithic culture. As the top of the peat unit at Yushan was eroded away by the storm in many units (Figs. 2, 3) or possibly lost due to human land use such as building an artificial platform (Table 1), we are unable to determine directly the age when the coastal marsh was inundated and buried by the marine sediments. We therefore compared the ages obtained from the rice field profiles at the Tianluoshan (TLS) site, which is only $\sim 20 \mathrm{~km}$ away from Yushan and is located inland and surrounded by highland (Fig. 1B). At the TLS site, the top of the corresponding peat bed formed during the Liangzhu period is non-erosively preserved and dateable (Zheng et al., 2012). This implies that this site was protected from the storm erosion and only drowned by the sea water. Thus, the buried peat top should represent the original depositional surface of the coastal marsh. Two samples of seeds from different trenches from the peat top of the TLS site resulted in the same age of $2540 \mathrm{BCE}\left({ }^{14} \mathrm{C}\right.$ ages of $4015 \pm 45$ and $4020 \pm 40 \mathrm{yr} \mathrm{BP}$, respectively, Table 2$)$. This corresponds very well with the Yushan profile, both in terms of the stratigraphy and the age of the marine inundation as dated by OSL (2575 BCE; Table 3). From these two reliable and independent lines of chronological evidence which give a range of 2540-2575 BCE for the central age, we therefore consider that the most likely date of the storm to be $\sim 2560 \pm 100 \mathrm{BCE}$ (the range of \pm 100 years was decided according to the error of radiocarbon dating). 
The Liangzhu people abandoned the Yushan site immediately after the storm event. Our compilation of radiocarbon ages of other sites across the south Yangtze coastal plains further demonstrates that the terminal age of the Liangzhu culture was at approximately 2500 BCE (Fig. 5), when the Liangzhu people abandoned their state capital complex (Zhang et al., 2015; Wang et al., 2017). Thus, the Liangzhu culture ended only decades after the Yushan storm. The subsequent Qianshanyang and Guangfulin cultures both lasted only for $\sim 300$ years, much shorter than the Liangzhu culture (Fig. 5).

\subsection{Relative sea-level change from 4500 to $1500 \mathrm{BCE}$}

The deposits of saltmarsh and freshwater marsh of layers 7 and 6, respectively imply that relative sea level dropped from $-0.78 \pm 0.22 \mathrm{~m}$ to $-1.10 \pm 0.25 \mathrm{~m}$ during the period from late Hemudu (3945-4170 BCE) to Liangzhu culture (2635-2880

BCE; Table 4; Fig. 6). We further interpolated an indicator of the peat top from the west part of unit T0513, where weak erosion of the peat occurred, and $\sim 30$-cm thick peat exists above the Holocene base (Fig. 2B). An original $\sim 40-\mathrm{cm}$ thickness of the peat was estimated using the highest estimation of percentage $(30 \%)$ of peat compaction with an overburden of $1 \mathrm{~m}$ (van Asselen et al., 2011). Thus, the original altitude of the peat top and the relative sea level was estimated to be at $1.16 \mathrm{~m}$ and $-0.70 \pm 0.25 \mathrm{~m}$, respectively (Table 4) when the storm occurred at $2560 \pm 100 \mathrm{BCE}$. The upper tidal flat facies of layer 4 indicates a high relative sea-level stand at $\sim 0.25 \pm$ $0.27 \mathrm{~m}$ at $2335-2495 \mathrm{BCE}$ while the saltmarsh sediments of layer 3 indicate the sea 
level was at $\sim 0.05 \pm 0.22 \mathrm{~m}$ at $1395-1500 \mathrm{BCE}$. These data suggest an acceleration in relative sea-level rise during the late stage of Liangzhu culture and a slight drop of the sea level from $\sim 2440$ BCE. In addition, a rapid relative sea-level rise also occurred from $-1.49 \pm 0.25 \mathrm{~m}$ to $-0.45 \pm 0.27 \mathrm{~m}$ from $4440-4540 \mathrm{BCE}$ to $4260-4360 \mathrm{BCE}$, inferred from the basal peat layer 9 and the marine-originated homogenous mud layer 8, respectively (Figs 2B, 4; Table 4). Similarly, this earlier acceleration of sea-level rise occurred during the cultural interruption period between early to mid-Hemudu and late Hemudu cultures (Fig. 6).

\section{Discussion}

\subsection{Flooding signatures across the south Yangtze coast}

From these multiproxy and independent lines of evidence, we speculate that a major coastal storm occurred at $\sim 2560 \pm 100 \mathrm{BCE}$, which not only overwhelmed the Yushan site directly, but was strong enough to erode away $\sim 30$-cm thick peat (Fig. 3). This storm was followed by long-lasting marine inundation and the development of a brackish tidal flat owing to relative sea-level rise, which led to human abandonment of the area for $\sim 1000$ years until $\sim 1625$ BCE (Figs. 4, 6). The brackish wetland ecosystem was characterised by low primary productivity, bacterial-dominated OC and low terrestrial OC input, probably with limited biomass production, and was unlikely to support significant human populations during the high sea-level stand of 2440-1625 BCE (Fig. 4). Although the wetland had become less saline by the time of the subsequent Shang, Zhou, Tang and Song dynasties (layers 2 and 3), we infer from 

coast (Fig. 6; Table 5) reveal the extent of this coastal flooding in response to the accelerated sea-level rise during the later stages of Neolithic culture. As expected, a strong saline event occurred at $\sim 2540$ BCE at sites within the Yaojiang plain (cf. at TSL; Zheng et al., 2012), but it is also clearly seen $140 \mathrm{~km}$ west (at KHQ; ZPICRA, 2004; Fig. 6). A slight increase in salinity (reflected by increase in the abundance of saline Chenopodiaceae) was also seen at the Liangzhu site close to the state capital

446 (Table 5). The marine flooding likely did not extend across the Taihu Plain, which 447 also had some protection from substantial chenier ridges to the east (Fig. 1), but there 448 is evidence of a salinization event at the same time at sites ZX-1, TMC (Fig. 6) and 449 Guangfulin (Table 5) close to the shoreline. At most other sites, an increase in local 450 water level was reported at the end of the Liangzhu period (Table 5), implying inland 451 flooding from storm rainfall or waterlogging due to sea-level rise.

\subsection{Causes of the mid-Holocene coastal flooding}

454 Our reconstruction of relative sea level demonstrated a rapid rise $(\sim 0.95 \mathrm{~m}$ in $455 \sim 120$ years; Table 4) at the final stage of the Liangzhu culture (Fig. 6). The amplitude 456 of this rise could be slightly overestimated because of the uncertainty in the height of 457 the top of the peat and the underestimation of its compaction. We also did not 
consider the enlargement of the tidal range because previous simulations demonstrated little change in the amplitude of the $\mathrm{M}_{2}$ tide in the south east Hangzhou Bay during the middle to late Holocene (Uehara et al., 2002). As previous studies further suggest no major deposition or shoreline advance during the middle Holocene along the Hangzhou Bay (Yan et al., 1989; Gao and Collins, 2014; Zhang et al., 2015), we infer no significant change in tidal levels after the Yushan storm 4500 years ago.

This accelerated relative sea-level rise is consistent with sea level records from other regions around the world, and adds to evidence that this rise may reflect a global signal, rather than resulting from local processes. For example, on the coast of Peninsular Malaysia, the relative sea level dropped slightly from 3500 to $2500 \mathrm{BCE}$ and then rose suddenly by $\sim 1-3 \mathrm{~m}$ from $\sim 2500$ to $2100 \mathrm{BCE}$ (Tjia, 1996; Horton et al., 2005). Rapid relative sea level rise between 2650 and 2350 BCE was also reported from the coast of north-eastern Brazil ( 1 m; Suguio et al., 2013) and the northern Gulf of Mexico (Balsillie and Donoghue, 2011). In the mid-Pacific Ocean, microatolls record a relative sea level rise beginning at $\sim 2500 \mathrm{BCE}$, following slightly declining or stable levels over the previous $\sim 1500$ years (Woodroffe et al., 2012). The eustatic sea level curve reconstructed from Red Sea corals shows that sea level began to rise at $\sim 2300$ BCE, following stable or declining levels over the previous $\sim 900$ years (Siddall et al., 2003). These data imply a small but significant acceleration in global sea level rise in the middle of the third millennium BCE. 

centennial timescales between 6850 and 6500 cal yr BP from the microatolls of the rapid rise of relative sea level at Yushan $\sim 4500$ years ago, together with the earlier rise $\sim 6300$ years ago (Fig. 6) have similarity with the records in the microatolls of the

Sunda Shelf. Furthermore, the record of the Asian summer monsoon shows a small peak in activity from 2600-2450 BCE (Fig. 6; Wang et al., 2005). A comparison of values between the Dongge Cave $\delta^{18} \mathrm{O}$, a proxy for the relative strength of the Asian summer monsoon, and atmospheric $\Delta^{14} \mathrm{C}$, a proxy for solar activity, revealed that the monsoon peak coincided with the peak in solar irradiance from $\sim 2600$ to $2400 \mathrm{BCE}$ (Stuiver, 1998; Wang et al., 2005). From these data, we infer that this small monsoon

491 intensity peak was driven by increasing solar activity and hence was a climatewarming event on a centennial timescale. Therefore, we suggest that accelerated

493 global sea-level rise occurred against a backdrop of climate warming during the late 494 stage of the Liangzhu culture. the return periods of flood events decrease as the sea level increases (Sweet et al.,

497 2014; Tessler et al., 2015). We thus suggest that the catastrophic storm at Yushan marked the beginning of a period of frequent flooding across the Yangtze coast, likely 
500

501

502

503

504

505

506

507

508

509

510

511

512

513

514

515

516

517

518

519

520

flood deposits in the coastal lowland of Hangzhou Bay and increasing freshwater levels across the Taihu Plain (Fig. 6; Table 5).

\subsection{Impacts of the coastal flooding on the Liangzhu human society}

We argue that perhaps only over a few decades, the combined effect of a series of extreme events and flooding, such as the Yushan inundation, could have

overwhelmed even a politically advanced, technologically capable and well-organised prehistoric society such as the Liangzhu. Frequent extreme events and flooding would have had profound impacts, both immediate and longer-term. The coastal storm recorded at Yushan at $2560 \mathrm{BCE}$ and associated flooding (including inland river

flooding from storm rainfall) would have destroyed settlements and infrastructure across the region, as seen in the archaeological record at Yushan (Fig. 3). In the Yaojiang Plain, the immediate aftermath of marine flooding would have killed freshwater wetland plant communities that could not tolerate higher salinity and thus ended rice cultivation (Zheng et al., 2012); low net biomass production under marine/brackish conditions (Fig. 4A) would be unlikely to support significant human populations. At the head of Hangzhou Bay, coastal flooding also inundated the lateLiangzhu rice paddies such as at Maoshan ( $\sim 30 \mathrm{~km}$ away from the Mojiaoshan, Fig. 1), notwithstanding it was designed with artificial ditches to facilitate water management (Zhuang et al., 2014). The political centre of Mojiaoshan was not only threatened directly by the salt intrusion and frequent flooding (Liu and Chen, 2012; 
Zhuang et al., 2014; Table 4), but also could have learned lessons from the flooding of inundated sites in the Yaojiang Plain.

Furthermore, although societal and demographic recovery from a single extreme event could have happened after the Yushan storm (e.g. during freshening seen in the upper section of layer 5; Fig. 4A), frequent flooding would have made this much more difficult, for example by ruining stored rice seeds or from persistent and widespread crop failure (Stone, 2009). This would quickly result in a shortage of surplus production needed to support the political centre, and the large number of artisanal workers not employed in food production, such as jade workers (Liu and Chen, 2012).

It is possible that the Liangzhu ruling political elite could have moved the state capital away from the coastal lowland as an adaptive strategy to mitigate the impacts of rising sea level and increasing flooding, potentially explaining the appearance of the subsequent, but less organised and less developed (yet culturally related), Qianshanyang culture. Owing to its profound impacts on the landscape and people, this period of flooding, including the Yushan storm at 2560 BCE, may even have contributed to the ancient oral flood traditions in the Lower Yangtze, forming the cultural setting for the legend of China's Great Flood more than 4000 years ago (Lewis, 2006).

\section{Conclusions}

From the sedimentary record at the Yushan archaeological site, and combined evidence from other sites in the south Yangtze coastal plain, we conclude that major 
coastal flooding occurred at the late stage of the Liangzhu culture. This flooding was characterized by extreme events, and was caused by short-term but significant acceleration in sea-level rise, which was possibly linked to a climate warming event on a centennial timescale. We suggest that the frequent extreme events and catastrophic flooding during warming climate phases are controlling factors in explaining Neolithic cultural transitions in the middle Holocene in the Yangtze coastal lowland, including the sudden and perplexing demise of the technologically advanced Liangzhu culture. Our finding of this catastrophic coastal flooding at the middle of third millennium BCE provides an analogue for flood risk, owing to the predicted high rate of sea level rise at the end of $21^{\text {st }}$ century (Nerem et al., 2018) and urgently calls for mitigation strategies to be put in place to protect vulnerable coastal populations worldwide against a similar scenario of abrupt sea level rise in the near future.

\section{Acknowledgements}

This study was supported by the National Natural Science Foundation of China (Grant No. 41576042). We are grateful to two anonymous reviewers for their helpful comments.

\section{References}

Atahan, P., Itzstein-Davey, F., Taylor, D., Dodson, J., Qin, J., Zheng, H., Brooks, A., 2008. Holocene-aged sedimentary records of environmental changes and early 
agriculture in the lower Yangtze, China. Quaternary Science Reviews 27, 556-570, doi:10.1016/j.quascirev.2007.11.003.

Balsillie, J.H., Donoghue, J.F., 2011. Northern Gulf of Mexico sea-level history for the past 20,000 years. In: Buster, N.A., and Holmes, C.W., eds, Gulf of Mexico Origin, Waters, and Biota: Volume 3, Geology. Texas A\&M University Press, Texas, pp 53-72.

Bøtter-Jensen, L., Andersen, C.E., Duller, G.A.T., and Murray, A.S., 2003. Developments in radiation, stimulation and observation facilities in luminescence measurements. Radiation Measurements 37, 535-541, doi: 10.1016/S13504487(03)00020-9.

Chen, J., 2002. The Neolithic culture and environment in the Yangtze delta plain. PhD. Thesis, Shanghai, East China Normal University, 109 p (in Chinese).

Chen, J.Y., Zhu, H.F., Dong, Y.F., Sun, J.M., 1985. Development of the Changjiang estuary and its submerged delta. Continental Shelf Research 4, 47-56.

Chen, Z., Wang, Z., Schneiderman, J., Cai, Y., 2005. Holocene climate fluctuations on millennium scale in the Yangtze delta of eastern China: implications and response. The Holocene 15, 917-926.

Duller, G.A.T., 2008. Single-grain optical dating of Quaternary sediments: why aliquot size matters in luminescence dating. Boreas 37, 589-612, doi: 10.1111/j.1502-3885.2008.00051.x.

Durcan, J.A., King, G.E., Duller, G.A.T., 2015. DRAC: Dose rate and age calculation for trapped charge dating. Quaternary Geochronology 28, 54-61.

Gao, S., Collins, M.B., 2014. Holocene sedimentary systems on continental shelves. Marine Geology 352, 268-294. 
Giosan, L., Syvitski, J., Constantinescu, S., Day, J., 2014. Climate change: protect the world's deltas. Nature 516, 31-33.

He, C.Q., Song, Z.C., Zhu, Y.H., 2009. Dinoflagellate fossil of China. Science Press, Beijing (in Chinese).

Hori, K., Saito, Y., Zhao, Q., Cheng, X., Wang, P., Sato, Y., Li, C., 2001. Sedimentary facies of the tide-dominated paleo-Changjiang (Yangtze) estuary during the last transgression. Marine Geology 177, 331-351.

Horton, B.P., Gibbard, P.L., Milne, G.M., Morley, R.J., Purintavaragul, C., Stargardt, J.M., 2005. Holocene sea levels and palaeoenvironments, Malay-Thai Peninsula, southeast Asia. The Holocene 15, 1199-1213.

Innes, J.B., Zong, Y., Wang, Z., and Chen, Z., 2014. Climatic and palaeoecological changes during the mid- to Late Holocene transition in eastern China: highresolution pollen and non-pollen palynomorph analysis at Pingwang, Yangtze coastal lowlands. Quaternary Science Reviews 99, 164-175, doi: 10.1016/j.quascirev.2014.06.013.

Itzstein-Davey, F., Atahan, P., Dodson, J., Taylor, D., Zheng, H., 2007. Environmental and cultural changes during the terminal Neolithic: Qingpu, Yangtze delta, eastern China. Holocene 17, 875-887, doi:10.1016/j.quascirev.2007.11.003.

Kopp, R.E., Kemp, A.C., Bittermann, K., Horton, B.P., Donnelly, J.P., Gehrels, W.R., Hay, C.C., Mitrovica, J.X., Morrow, E.D., and Rahmstorf, S., 2016. Temperaturedriven global sea-level variability in the Common Era. Proc. Natl. Acad. Sci. USA 113, E1434-E1441, doi: 10.1073/pnas.1517056113. 
Lamb, A.L., Wilson, G.P., and Leng, M.J., 2006. A review of coastal palaeoclimate and relative sea-level reconstructions using $\delta^{13} \mathrm{C}$ and $\mathrm{C} / \mathrm{N}$ ratios in organic material. Earth-Science Reviews 75, 29-57, doi: 10.1016/j.earscirev.2005.10.003.

Lawler, A., 2009. Beyond the Yellow River: how China became China. Science 325, 930-935, doi: 10.1126/science.325_930.

Lewis, M.E., 2006. The Flood Myths of Early China. New York, State University of New York Press, 256 p.

Li, C., Wang, P., Sun, H., Zhang, J., Fan, D., Deng, B., 2002. Late Quaternary incisedvalley fill of the Yangtze delta (China): its stratigraphic framework and evolution. Sedimentary Geology 152, 133-158.

Li, Y., Wu, J., Hou, S., Shi, C., Mo, D., Liu, B., Zhou, L., 2010. Palaeoecological records of environmental change and cultural development from the Liangzhu and Qujialing archaeological sites in the middle and lower reaches of the Yangtze River. Quaternary International 227, 29-37, doi:10.1016/j.quaint.2010.05.015.

Liu, L., Chen, X., 2012. The Archaeology of China: From the Late Paleolithic to the Early Bronze Age (Cambridge World Archaeology). Cambridge, Cambridge University Press, 475 p.

Liu, C., Sui, J., He, Y., Hirshfield, F., 2013. Changes in runoff and sediment load from major Chinese rivers to the Pacific Ocean over the period 1955-2010. International Journal of Sediment Research 28, 486-495.

Liu, B., Wang, N., Chen, M., Wu, X., Mo, D., Liu, J., Xu, S., Zhuang, Y., 2017. Earliest hydraulic enterprise in China, 5,100 years ago. PNAS 114, 13637-13642. 
Mao, L.M., Wang, W.M., Shu, J.W., Yang, X.L., 2011. Holocene spores and microscopic algae from the Yangtze delta, east China Acta palaeontologica Sinica 50, 154-165 (in Chinese, with English abstract).

Meltzner, A.J., Switzer, A.D., Horton, B.P., Ashe, E., Qiu, Q., Hill, D.F., Bradley, S.L., Kopp, R.E., Hill, E.M., Majewski, J.M., Natawidjaja, D.H., and Suwargadi, B.W., 2017. Half-metre sea-level fluctuations on centennial timescales from midHolocene corals of Southeast Asia. Nature Communications 8, 14387, doi: 10.1038/ncomms 14387.

Moore, P.D., Webb, J.A., Collinson, M.E., 1990. Pollen analysis. Blackwell Scientific Publications, Oxford.

Nerem, R.S., Beckley, B.D., Fasullo, J.T., Hamlington, B.D., Masters, D., Mitchum, G.T., 2018. Climate-change-driven accelerated sea-level rise detected in the altimeter era. Proc. Natl. Acad. Sci. USA, doi: 10.1073/pnas.1717312115.

Nicholls, R.J., and Cazenave, A., 2010. Sea-level rise and its impact on coastal zones. Science 328, 1517-1520, doi: 10.1126/science.1185782.

Qin, L., 2013. The Liangzhu Culture. In: Underhill, A.P. (ed.), A Companion to Chinese Archaeology. Wiley-Blackwell, pp 574-598.

Qin, J., Taylor, D., Atahan, P., Zhang, X., Wu, G., Dodson, J., Zheng, H., ItzsteinDavey, F., 2011. Neolithic agriculture, freshwater resources and rapid environmental changes on the lower Yangtze, China. Quaternary Research 75, 55-65, doi: 10.1016/j.yqres.2010.07.014.

Renberg, I., 1990. A procedure for preparing large sets of diatom slides from sediment cores. Journal of Paleolimnology 4, 87-90. 
Ryves, D.B., Clarke, A.L., Appleby, P.G., Amsinck, S.L., Jeppesen, E., Landkildehus, F., and Anderson, N.J., 2004. Reconstructing the salinity and environment of the Limfjord and Vejlerne Nature Reserve, Denmark, using a diatom model for brackish lakes and fjords. Canadian Journal of Fisheries \& Aquatic Sciences 61, 1988-2006, doi: 10.1139/F04-127.

Shanghai Museum, 2002. The excavated report on the Neolithic site GUANG FU LIN, Songjiang, Shanghai during 1999-2000. KAO GU (10), 31-48 (in Chinese).

Shennan, I., Long, A.J., Horton, B.P., 2015. Handbook of sea-level research. John

$$
\text { Wiley \&Sons, Ltd. }
$$

Siddall, M., Rohling, E.J., Almogi-Labin, A., Hemleben, Ch., Meischner, D., Schmelzer, I., and Smeed, D.A., 2003. Sea-level fluctuations during the last glacial cycle. Nature 423, 853-858, doi: 10.1038/nature01690.

Stanley, D.J., Chen, Z., and Song, J., 1999. Inundation, sea-level rise and transition from Neolithic to Bronze age cultures, Yangtze delta, China. Geoarchaeology 14, $15-26$.

Stone, R., 2009. One year after a devastating cyclone, a bitter harvest. Science 324, 715, doi: 10.1126/science.324_715.

Stuiver, M., 1998. INTCAL 98 radiocarbon age calibration, 24,000-0 cal BP. Radiocarbon 40, 1041-1083.

Stuiver, M., Reimer, P.J., Reimer, R., 2015. CALIB: Radiocarbon Calibration: http://calib.qub.ac.uk/calib/(September 2015).

Sun, D., Gagan, M.K., Cheng, H., Scott-Gagan, H., Dykoski, C.A., Edwards, R.L., and Su, R., 2005. Seasonal and interannual variability of the Mid-Holocene East 
Asian monsoon in coral $\delta^{18} \mathrm{O}$ records from the South China Sea. Earth and Planetary Science Letters 237, 69-84.

Suguio, K., Barreto, A.M.F., de Oliveira, P.E., Bezerra, F.H.R., and Vilela, M.C.S.H., 2013. Indicators of Holocene sea level changes along the coast of the states of Pernambuco and Paraíba, Brazil. Geologia USP 13, 141-152, doi: 10.5327/Z1519-874X201300040008.

Sweet, W., Park, J., Marra, J., Zervas, C., and Gill, S., 2014. Sea level rise and nuisance flood frequency changes around the United States. NOAA Technical Report NOS CO-OPS 073, 58 p.

Syvitski, J.P.M., Kettner, A.J., Overeem, I., Hutton, E.W.H., Hannon, M.T., Brakenridge, G.R., Day, J., Vorosmarty, C., Saito, Y., Giosan, L., and Nicholls, R.J., 2009. Sinking deltas due to human activities. Nature Geoscience 2, 681-686.

Tang, L.Y., Mao, L.M., Li, X.M., 2013. Palaeoecological and palaeoenvironmental significance of some important spores and micro-algae in Quaternary deposits. Chinese Science Bulletin 58, 3125-3139.

Tessler, Z.D., Vörösmarty, C.J., Grossberg, M., Gladkova, I., Aizenman, H., Syvitski, J.P.M., and Foufoula-Georgiou, E., 2015. Profiling risk and sustainability in coastal deltas of the world. Science 349, 638-643, doi: 10.1126/science.aab3574. Tjia, H.D., 1996. Sea-level changes in the tectonically stable Malay-Thai Peninsular. Quaternary International 31, 95-101.

Uehara, K., Saito, Y., Hori, K., 2002. Paleotidal regime in the Changjiang (Yangtze) Estuary, the East China Sea, and the Yellow Sea at 6 ka and 10 ka estimated from a numerical model. Marine Geology 183, 179-192. 
van Asselen, S., Karssenberg, D., Stouthamer, E., 2011. Contribution of peat compaction to relative sea-level rise within Holocene deltas. Geophysics

$$
\text { Research Letters 38, L24401, doi:10.1029/2011GL049835. }
$$

Wang, X., Mo, D., Li, C., Yu, S.-Y., Xue, B., Liu, B., Wang, H., and Shi, C., 2017. Environmental changes and human activities at a fortified site of the Liangzhu culture in eastern China: evidence from pollen and charcoal records. Quaternary International 438, 189-197, doi: 10.1016/j.quaint.2017.05.001.

Wang, Y., Cheng, H., Edwards, R.L., He, Y., Kong, X., An, Z., Wu, J., Kelly, M.J., Dykoski, C.A., and Li, X., 2005. The Holocene Asian monsoon: links to solar changes and North Atlantic climate. Science 308, 854-857, doi: 10.1126/science. 1106296 .

Wang, Z., Li, M., Zhang, R., Zhuang, C., Liu, Y., Saito, Y., Xie, J., Zhao, B., 2011. Impacts of human activity on the late-Holocene development of the subaqueous Yangtze delta, China, as shown by magnetic properties and sediment accumulation rates. The Holocene 21, 393-407.

Wang, Z., Zhuang, C., Saito, Y., Chen, J., Zhan, Q., and Wang, X., 2012. Early midHolocene sea-level change and coastal environmental response on the southern Yangtze delta plain, China: implications for the rise of Neolithic culture. Quaternary Science Reviews 35, 51-62, doi: 10.1016/j.quascirev.2012.01.005.

Wang, Z., Zhan, Q., Long, H., Saito, Y., Gao, X., Wu, X., Li, L., Zhao, Y., 2013. Early to mid-Holocene rapid sea-level rise and coastal response on the southern Yangtze delta plain, China. Journal of Quaternary Science 28, 659-672. 
Woodroffe, C.D., McGregor, H.V., Lambeck, K., Smithers, S.G., and Fink, D., 2012. Mid-Pacific microatolls record sea-level stability over the past $5000 \mathrm{yr}$. Geology 40, 951-954, doi: 10.1130/G33344.1.

Woodruff, J.D., Irish, J.L., and Camargo, S.J., 2013. Coastal flooding by tropical cyclones and sea-level rise. Nature 504, 44-52, doi: 10.1038/nature12855.

Yan, Q., Xu, S., and Shao, X., 1989. Holocene cheniers in the Yangtze Delta, China. Marine Geology 90, 337-343.

Zhan, Q., Wang, Z., Xie, Y., Xie, J., He, Z., 2011. Assessing C/N and $\delta^{13} \mathrm{C}$ as indicators of Holocene sea level and freshwater discharge changes in the subaqueous Yangtze delta, China. The Holocene 22, 697-704.

Zhang, X., Dalrymple, R.W., Yang, S.-Y., Lin, C.-M., Wang, P., 2015. Provenance of Holocene sediments in the outer part of the paleo-Qiantang River estuary, China. Marine Geology 366, 1-15.

Zhang, X., Huang, D., Deng, H., Snape, C., Meredith, W., Zhao, Y., Du, Y., Chen, X., and Sun, Y., 2015. Radiocarbon dating of charcoal from the Bianjiashan site in Hangzhou: New evidence for the lower age limit of the Liangzhu Culture. Quaternary Geochronology 30, 9-17, doi: 10.1016/j.quageo.2015.07.001.

Zhao, X., 1998. Origin of rice paddy cultivation at the Hemudu site. Agricultural Archaeology 1, 131-137. Scanned by Sui, K.; form. by Leir, G.; transl./ed. by Gordon, B., Wong, E., Craig, A..

Zheng, Y., Sun, G., Qin, L., Li, C., Wu, X., and Chen, X., 2009. Rice fields and modes of rice cultivation between 5000 and $2500 \mathrm{BC}$ in east China. Journal of Archaeological Science 36, 2609-2616, doi: 10.1016/j.jas.2009.09.026. 
Zheng, Y.F., Sun, G.P., and Chen, X.G., 2012. Response of rice cultivation to fluctuating sea level during the Mid-Holocene. Chinese Science Bulletin 57, 370 378, doi: 10.1007/s11434-011-4786-3.

Zhuang, Y., Ding, P., and French, C., 2014. Water management and agricultural intensification of rice farming at the late-Neolithic site of Maoshan, Lower Yangtze River, China. The Holocene 24, 531-545, doi: $10.1177 / 0959683614522310$.

Zong, Y., Chen, Z., Innes, J.B., Chen, C., Wang, Z., and Wang, H., 2007. Fire and flood management of coastal swamp enabled first rice paddy cultivation in east China. Nature 449, 459-462, doi: 10.1038/nature06135.

Zong, Y., Innes, J.B., Wang, Z., and Chen, Z., 2011. Mid-Holocene coastal hydrology and salinity changes in the east Taihu area of the lower Yangtze wetlands, China. Quaternary Research 76, 69-82, doi:10.1016/j.yqres.2011.03.005.

Zong, Y., Innes, J.B., Wang, Z., and Chen, Z., 2012. Environmental change and Neolithic settlement movement in the lower Yangtze wetlands of China. The Holocene 22, 659-673, doi: 10.1177/0959683611414933.

ZPICRA, 2004. KUA HU QIAO-Archaeological Report of Puyang River Valley I. Beijing, WEN WU Press, 379 p (in Chinese).

ZPICRA, Huzhou Museum, 2014. Qianshanyang: a report on the third and fourth excavations of the site. Beijing, WEN WU Press, $738 \mathrm{p}$ (in Chinese).

\section{Table headings}

Table 1 A summary of the archaeological sequence at Yushan site (Figs 2, 3). 
Table 2 AMS ${ }^{14} \mathrm{C}$ ages and their calibrations for the Yushan and Tianluoshan sites.

772 Table 3 Single-grain OSL age for the sand ridge sample from the Yushan site

773 together with supporting dose rate and equivalent dose $\left(\mathrm{D}_{\mathrm{e}}\right)$ data.

774 Table 4 Reconstruction of relative sea levels using sea-level indicators obtained from

775 units T0410 and T0513 (Fig. 2B, C). Sedimentary facies was determined according to

776 the lithology, organic carbon, diatom assemblage and dinoflagellate cysts. Tidal levels

777 were collected from the Zhenhai gauge station (Fig. 1; 1958-1980). MSHW, $1.61 \mathrm{~m}$;

778 MHW, $1.17 \mathrm{~m}$; MNHW, $0.63 \mathrm{~m}$. All heights are given with respect to current mean

779 sea level (Yellow Sea datum). Abbreviations: MSHW, mean spring high water;

780 MHW, mean high water; MNHW, mean neap high water.

781 Table 5 Sediment profiles with high-resolution AMS ${ }^{14} \mathrm{C}$ ages from the Taihu and

782 Yaojiang Plains and head of the Hangzhou Bay, East China coast. Locations of these

783 profiles are indicated in Fig. S2.

784

785

Figure legends

Figure 1 Location maps. (A) East Asia and the location of the study area. (B) The south Yangtze coastal plain, showing the locations of the Liangzhu sites and all sites for which radiocarbon dates for the Liangzhu and post-Liangzhu cultural layers were available. These sites are numbered in sequence according to their distance from the Yushan site (Table S1). Note that the Liangzhu settlements are distributed mainly on the Taihu Plain of the southern Yangtze Delta plain and the Yaojiang Plain on the

792 south east bank of Hangzhou Bay. (C) The flooding to a depth of $>0.5 \mathrm{~m}$ across most 793 of the Yaojiang Plain caused by Typhoon Fitow (the strongest typhoon to make 
landfall in China for over 60 years), October 2013 (data source: Ningbo gauge station, 2013. http://www.nbswz.com.cn/Html/201405/26/11669.html). (D-F) Typical artefacts of the Liangzhu culture discovered from the Yushan site, now deposited in Ningbo Municipal Institute of Cultural Relics and Archaeology. (D) Stone cutter (Shi Dao); (E) stone woodworking tool (Youduan Shi Beng); (F) black pottery two-lugged necked jar (Shuangbi Hu), with some remains of black slip. The maps were generated with the ArcGis 10.1 software (www.esrichina.com.cn) using the topographic dataset provided by the International Scientific \& Technical Data Mirror Site, Computer Network Information Centre, Chinese Academy of Sciences (http://www.gscloud.cn). Figure 2 (A). Aerial photo of the Yushan site during excavation. (B) Photo of the south wall of unit T0513. Numbers represent the cultural layers. Note layers 8 and 9 pinch out and disappear westward due to the basal topography, making layer 6 the Holocene basal peat in some sections. (C) Photo of the west wall of unit T0410. Numbers represent the cultural layers. The data set of altitude and radiocarbon age are presented for each sea-level indicator in (B) and (C). Layers 8 and 9 also pinch out and disappear northward due to the basal topography, making layer 7 the Holocene basal sediments. Elevation of the Holocene bases in two units were measured by a total station. White arrows with elevation and calibrated ages (BCE) represent data used for reconstruction of relative sea level. Numbers of cultural layers: 2, Tang to Song dynasties; 3, Shang to Zhou dynasties; 4-5, natural deposits; 6a-6b, Liangzhu period; 7, late Hemudu period, missing in these units; $\mathbf{8}$, natural deposits; $\mathbf{9}$, early to middle Hemudu period; 10, pre-Hemudu natural deposits.

Figure 3 Photographs of strata at Yushan. (A) Excavation unit T0513, showing the sediments deposited since the pre-Hemudu period and the erosional surface above the 
peat layer of the Liangzhu period. (B-C) Tree stumps on the tops of the peat layers in T0213 and T0214. (D) Sand ridge in T0415. (E-F) Sand ridge in T0513.

Figure 4 Environmental change and human responses at Yushan. (A)

Stratigraphic patterns of total nitrogen (TN), total organic carbon (TOC), TOC/TN, bulk organic carbon stable isotopic composition $\left(\delta^{13} \mathrm{C}\right)$, dinoflagellate cysts, diatoms $(\mathrm{N}=$ none, $\mathrm{F} / \mathrm{B}=$ freshwater/brackish; $\mathrm{M}=$ marine; detailed information in Table $\mathrm{S} 4)$ and sedimentation rates (SR) in different cultural layers (2-10). The numbers used for the cultural layers are the same as in Fig. 3. Ages with stars $\left(^{*}\right)$ were calculated based on sedimentation rates. (B) Discrimination of organic carbon sources based on TOC/TN and $\delta^{13} \mathrm{C}$ (adapted from Lamb et al., 2006).

Figure 5 Time span of the Liangzhu (Group 1), Qianshanyang (Group 2), Guangfulin (Group 3) cultures and post-Liangzhu natural deposits in Yaojiang plain (Group 4). Note the end of the Liangzhu culture is around $2500 \mathrm{BCE}$. Also indicated is the OSL age of the storm sand at the top of the Liangzhu cultural layer (boundary of layer 5/6a; Fig. 3). Site number ordered by distance from the Yushan site (Fig. 1; Table S1). Samples dated by $\mathrm{AMS}{ }^{14} \mathrm{C}$ are indicated in red. Others were dated by the radiometric method.

Figure 6 Comparison of the relative sea-level change and regional marine

flooding records on the south Yangtze coast from the Yaojiang and Taihu plains and the head of Hangzhou Bay. In the sea-level curve, calibrated radiocarbon ages are presented with error bars of $2 \sigma$; horizontal error bars represent the indicative meaning (range of relative sea level) of each sea-level indicator. The interpolated data point is calculated from the data set derived from the estimated storm age and original peat top (Table 4; see text for details). Sediment profiles are numbered as in Fig. S2 (with increasing distance from Yushan); data sources are given in Tables 4 and S2. 
843 The oxygen isotopic record $\left(\delta^{18} \mathrm{O}\right)$ of stalagmite DA from Dongge Cave (the cave

844 location is marked in Fig. 1A; Wang et al., 2005) denotes a short period of

845 strengthening, yet variable, Asian summer monsoon linked to the warming climate

846 (denoted by the red arrow) during the latter stages of the Liangzhu culture.

847

848

849

850

851

852

853

854

855

856

857

858

859

860 
Table 1 A summary of the archaeological sequence at Yushan site (Figs 2, 3).

\begin{tabular}{|c|c|c|c|}
\hline $\begin{array}{l}\text { Cultural } \\
\text { layer }\end{array}$ & Description of lithology & Archaeological finds & Cultural period \\
\hline 1 & Cultivated layer. & None & Present-day \\
\hline 2 & Yellowish earth. & Yue Kiln & Tang and Song \\
\hline 3 & Dark grey or yellowish grey mud. & $\begin{array}{l}\text { Pottery vessels, early proto-celadon, bronze ware, stone and wood } \\
\text { tools }\end{array}$ & Shang and Zhou \\
\hline 4 & $\begin{array}{l}\text { Yellowish grey mud with some very thin }(<1 \mathrm{~mm}) \\
\text { laminations of silt and abundant root traces. }\end{array}$ & None & Cultural interruption \\
\hline $5 \mathrm{a}$ & $\begin{array}{l}\text { Grey homogeneous mud with an unconformity with the } \\
\text { underlying layer } 6 \text {. }\end{array}$ & None & Cultural interruption \\
\hline & $\begin{array}{l}\text { erosional surface occurred and tree stumps exist in many } \\
\text { units (Fig. 3A-C). }\end{array}$ & $\begin{array}{l}\text { pottery vessels, polished stone tools of axe, adze, plow, cutter, } \\
\text { arrowhead, sickle and Mopan slab. Some artefacts were also found in } \\
\text { the peaty mud and peat. }\end{array}$ & \\
\hline
\end{tabular}


7

Organic rich mud

Grey homogeneous mud.

Dark grey peaty mud

10

Yellowish grey or grey homogeneous mud
Red pottery vessels, polished stone tools of axe, adze, chisel, arrow

Late Hemudu

head and Mopan slab and jade.

None

Cultural interruption

Black pottery vessels, polished stone tools of axe and adze, bone awl Early to middle Hemudu and remains of architecture.

None

Natural deposition before

settling 

Table 2 AMS ${ }^{14} \mathrm{C}$ ages and their calibrations for the Yushan and Tianluoshan sites.

\begin{tabular}{|c|c|c|c|c|c|c|c|c|c|}
\hline Field number & $\begin{array}{l}\text { Cultural } \\
\text { period }\end{array}$ & $\begin{array}{l}\text { Cultural } \\
\text { layer }\end{array}$ & $\begin{array}{l}\text { Dating } \\
\text { material }\end{array}$ & $\delta^{13} \mathrm{CC}$ & $\begin{array}{c}\text { Conventional } \\
\text { age }\end{array}$ & Cali & $\begin{array}{l}\text { ibrated age } \\
\text { (BCE) }\end{array}$ & I & $\begin{array}{c}\text { Laboratory } \\
\text { Number }\end{array}$ \\
\hline & & (Fig. 3) & & $(\%)$ & $\mathrm{aBP}$ & 2 sigma & Probability & yMedian & \\
\hline T0410-3c & Shang & 3 & Charcoal & $1-25.2$ & $3170 \pm 30$ & $1395-1500$ & 1 & 1450 & 414776 \\
\hline T0410-4 & None & 4 & $\begin{array}{c}\text { Plant } \\
\text { fragments }\end{array}$ & s -27.9 & $3940 \pm 30$ & $2335-2495$ & 0.90 & 2440 & 414777 \\
\hline $\mathrm{T} 0513-5^{*}$ & None & 5 & $\begin{array}{c}\text { Plant } \\
\text { fragments }\end{array}$ & -25.5 & $4170 \pm 30$ & $2635-2880$ & 1 & 2760 & 406454 \\
\hline Т0513-6a & Liangzhu & $6 a$ & $\begin{array}{c}\text { Plant } \\
\text { fragments }\end{array}$ & -30.3 & $4170 \pm 30$ & $2635-2880$ & 1 & 2760 & 406455 \\
\hline T0410-6b & Liangzhu & $6 b$ & $\begin{array}{l}\text { Organic } \\
\text { sediments }\end{array}$ & -27.6 & $4770 \pm 30$ & $3515-3640$ & 0.98 & 3570 & 414778 \\
\hline T0410-7 & $\begin{array}{l}\text { Late } \\
\text { Hemudu }\end{array}$ & $7 a$ & Charcoal & -25.6 & $5210 \pm 50$ & $3945-4170$ & 0.94 & 4020 & 414779 \\
\hline Т0513-8-1 & None & 8 & $\begin{array}{c}\text { Plant } \\
\text { fragments }\end{array}$ & NA & $5470 \pm 30$ & $4260-4360$ & 1 & 4310 & 406456 \\
\hline T0513-9 & $\begin{array}{l}\text { Early to } \\
\text { mid- } \\
\text { Hemudu }\end{array}$ & 9 & Charcoal & -26.3 & $5640 \pm 30$ & $4440-4540$ & 0.83 & 4490 & 406457 \\
\hline Tianluoshan $^{\dagger}$ & $\begin{array}{l}\text { End of the } \\
\text { Neolithic }\end{array}$ & - & Seeds & $\mathrm{NA}$ & $4020 \pm 402$ & $2465-2635$ & 0.98 & 2540 & BA091045 \\
\hline Tianluoshan & $\begin{array}{l}\text { End of the } \\
\text { Neolithic }\end{array}$ & - & Seeds & $\mathrm{NA}$ & $4015 \pm 45$ & $2455-2675$ & 0.97 & 2540 & BA07761 \\
\hline
\end{tabular}

$864{ }^{*}$ This sample was collected from the sand ridge.

$865 \dagger+$ Ages for Tianluoshan were obtained from Zheng et al., $(2009 ; 2012)$ and

866 recalibrated using the Calib 7.1 program, as were other ages in the present study. 
867 Table 3 Single-grain OSL age for the sand ridge sample from the Yushan site together with supporting dose rate and equivalent dose $\left(D_{e}\right)$ data.

868

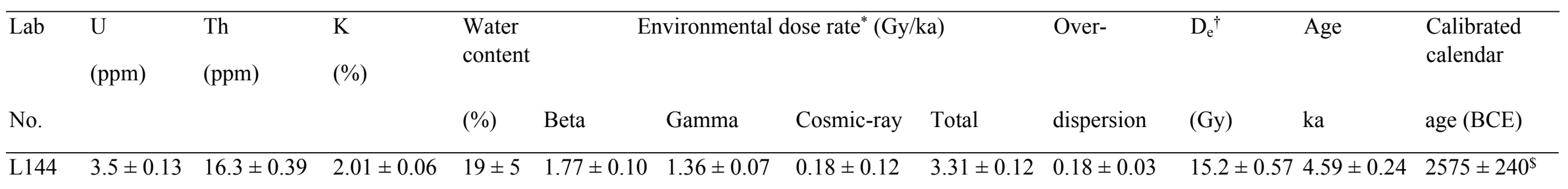

* The dose rate and OSL ages were calculated using the 'DRAC' (Durcan et al., 2015).

† Single grains of quartz were measured in the regenerative-dose protocol, using a test-dose of $3.03 \mathrm{~Gy}$, a preheat of $200{ }^{\circ} \mathrm{C}$ for $10 \mathrm{~s}$, a $160{ }^{\circ} \mathrm{C}$ cut heat for $0 \mathrm{~s}$, and green-laser stimulation at $125^{\circ} \mathrm{C}$ for $0.9 \mathrm{~s}$. The first $0.06 \mathrm{~s}$ of stimulation minus a background estimated from the integral of the last $0.1 \mathrm{~s}$ was used for

872 single grain $\mathrm{D}_{\mathrm{e}}$ calculation.

$873 \$$ This calibrated calendar age was calculated by subtracting 2015 that is the sampling year of the sand ridge from the OSL-dated age $4.59 \pm 0.24$ ka. 
Table 4 Reconstruction of relative sea levels using sea-level indicators obtains from units T0410 and T0513 (Fig. 2B, C). Sedimentary facies was determined according to the lithology, organic carbon, diatoms and dinoflagellate cysts. Tidal levels were collected from the Zhenhai gauge station (Fig. 1; 1958-1980). MSHW, 1.61 m; MHW, 1.17 m; MNHW, 0.63 m. All heights are given with respect to current mean sea level (Yellow Sea datum). Abbreviations: MSHW, mean spring high water; MHW, mean high water; MNHW, mean neap high water.

\begin{tabular}{|c|c|c|c|c|c|c|c|}
\hline \multirow{4}{*}{ Unit } & Alt. & Cultural & Sedimentary & Calibrated & Indicative & Palaeo- & Error \\
\hline & \multirow{3}{*}{ (m) } & \multirow{3}{*}{ layer } & \multirow{3}{*}{ facies } & \multirow{3}{*}{ age (BCE) } & \multirow{3}{*}{ meaning } & sea & \multirow{3}{*}{$(\mathrm{m})$} \\
\hline & & & & & & level & \\
\hline & & & & & & (m) & \\
\hline T0410 & 1.44 & 3 & Saltmarsh & $1395-1500$ & MHW-MSHW & 0.05 & 0.22 \\
\hline T0410 & 1.15 & 4 & Upper tidal flat & $2335-2495$ & MNHW-MHW & 0.25 & 0.27 \\
\hline \multirow{2}{*}{ T0513 } & \multirow{2}{*}{$1.16^{\dagger}$} & \multirow{2}{*}{6} & Freshwater/ & \multirow{2}{*}{$2560^{*}$} & $0-0.5 \mathrm{~m}$ above & \multirow{2}{*}{-0.70} & \multirow{2}{*}{0.25} \\
\hline & & & brackish marsh & & MSHW & & \\
\hline \multirow{2}{*}{ T0513 } & \multirow{2}{*}{0.76} & \multirow{2}{*}{6} & \multirow{2}{*}{ Freshwater marsh } & \multirow{2}{*}{$2635-2880$} & $0-0.5 \mathrm{~m}$ above & \multirow{2}{*}{-1.10} & \multirow{2}{*}{0.25} \\
\hline & & & & & MSHW & & \\
\hline T0410 & 0.61 & 7 & Saltmarsh & $3945-4170$ & MHW-MSHW & -0.78 & 0.22 \\
\hline T0513 & 0.45 & 8 & Upper tidal flat & $4260-4360$ & MNHW-MHW & -0.45 & 0.27 \\
\hline \multirow{2}{*}{ T0513 } & \multirow{2}{*}{0.37} & \multirow{2}{*}{9} & \multirow{2}{*}{ Freshwater marsh } & $1440 \quad 1540$ & $0-0.5 \mathrm{~m}$ above & \multirow{2}{*}{-1.49} & \multirow{2}{*}{0.25} \\
\hline & & & & $4+40-4 J 40$ & MSHW & & \\
\hline
\end{tabular}

* This is the interpolated age, i.e., the age of storm event that drowned the peat layer.

$\dagger$ Calibrated value of the original peat top assuming that the peat layer above Holocene base in the west part of T0513 was $\sim 30$-cm thick, and had been compacted from an original $\sim 40-\mathrm{cm}$ thick layer, using the highest estimation of percentage (30\%) of peat compaction with an overburden of $1 \mathrm{~m}$ (van Asselen et al., 2011). 
Table 5 Sediment profiles with high-resolution AMS ${ }^{14} \mathrm{C}$ ages from the Taihu and Yaojiang Plains and head of the Hangzhou Bay, East China coast. Locations of these profiles are indicated in Fig. S2.

\begin{tabular}{|c|c|c|c|c|c|c|c|c|}
\hline $\begin{array}{l}\text { No. } \\
\text { (Fig. } \\
\text { 1) }\end{array}$ & Name of site & $\begin{array}{l}\text { Dated period } \\
\text { (BCE unless } \\
\text { stated as } \\
\text { AD) }\end{array}$ & $\begin{array}{l}\text { Number of } \\
\text { dates from } \\
2000-3000 \\
\text { BCE }\end{array}$ & $\begin{array}{l}\text { Covering the } \\
\text { end of } \\
\text { Liangzhu } \\
\text { culture }(\mathrm{Y} / \mathrm{N})\end{array}$ & $\begin{array}{l}\text { Ecological and } \\
\text { environmental } \\
\text { indicators at the end } \\
\text { of Liangzhu culture } \\
(\mathrm{Y} / \mathrm{N})\end{array}$ & Proxy & Signal of flooding & Data source \\
\hline$\overline{1}$ & Yushan & $1450-4490$ & $4+1$ (OSL) & $\mathrm{Y}$ & $\begin{array}{l}\mathrm{Y}(\text { sedimentation } \\
\left.\text { rate: } 0.5-4 \mathrm{~mm} \mathrm{yr}^{-1}\right)\end{array}$ & $\begin{array}{l}\text { Lithology, } \\
\text { sedimentology, } \\
\text { organic } \\
\text { geochemistry, } \\
\text { diatom, macroflora }\end{array}$ & Storm and marine flooding & Present study \\
\hline 2 & $\begin{array}{l}\text { Tianluoshan } \\
\text { (TLS) }\end{array}$ & $0-5080$ & 2 & $\mathrm{Y}$ & $\mathrm{Y}$ & $\begin{array}{l}\text { Diatom, phytoliths, } \\
\text { macroflora }\end{array}$ & Marine flooding & $\begin{array}{l}\text { Zheng et al., } \\
2016\end{array}$ \\
\hline 3 & $\begin{array}{l}\text { Kuahuqiao } \\
\text { (KHQ) }\end{array}$ & $1160-9020$ & 1 & $\mathrm{Y}$ & $\mathrm{Y}$ & Lithology & Marine flooding & ZPICRA, 2004 \\
\hline 4 & $\begin{array}{l}\text { Tangmiaocun } \\
(\mathrm{TMC})^{*}\end{array}$ & $2730-4020$ & 1 & Y & Y & $\begin{array}{l}\text { Diatom, rice } \\
\text { phytoliths }\end{array}$ & Slight increase in salinity & $\begin{array}{l}\text { Zong et al., } \\
2011\end{array}$ \\
\hline 5 & ZX-1 & $685-6650$ & 1 & $\mathrm{Y}$ & $\mathrm{Y}$ & Pollen, foraminifera & Marine flooding & $\begin{array}{l}\text { Stanley et al., } \\
\text { 1999; Chen et } \\
\text { al., } 2005\end{array}$ \\
\hline
\end{tabular}


Luojiang/

AD 955 8155

Hemudu

0 Guangfulin

AD

860-4360

\section{Siqian}

$4290-6160$

0

12 Tinglin

$4640-6250 \quad 0$

13 Longnan

2860-3580 1

$14 \quad$ Yuanjiadi
1920-4430 0
Limited data due to very low

sedimentation rate

(0.1 $\mathrm{mm} \mathrm{yr}^{-1}$ )

Hiatus inferred from Pollen the radiocarbon age

(sedimentation rate:

$0.1 \mathrm{~mm} \mathrm{yr}^{-1}$ )

$\mathrm{N}$

$\mathrm{N}$

Y

Y

Y

Y

N

N

Y

Y
Pollen

P

(1)

Pollen

Pollen

Pollen

(n)

Diatom

Diatom, rice phytoliths

Pollen

Pollen
Increase in local water level Innes et al., 2014

Qin et al., 2011

Qin et al., 2011

Increase in local water Itzstein-Davey level ${ }^{\dagger} \quad$ et al., 2007

Increase in local water Chen, 2002;

level ${ }^{\S}$ and increase in saline Atahan et al., biota (Chenopodiaceae) 2008; Wang et al., 2012

Zong et al., 2011

Zong et al., 2011

Increase in local water level Zong et al., 2012

Increase in local water level Zong et al., 2012 


\section{N}

$\mathrm{N}$

$\mathrm{N}$

Y

Y

N

$\mathrm{N}$

Uncertain due $\mathrm{Y}$

to no age

constrain
Pollen

Pollen -

Pollen

$-$

Increase in local water level"

$-$

Increase in saline biota (Chenopodiaceae)
Zong et al., 2012

Zong et al., 2012

Zong et al., 2012

Zong et al., 2012

Li et al., 2010

*The name "Tangcunmiao" in the original paper should be "Tangmiaocun".

$\dagger$ Age-depth model determined by excluding results from old carbon. Increase in local water level is inferred from the increase in abundance of Typha and Triglochin-Potamogeton type and a decrease in Artemisia.

\$There are two profiles at this site, one from Atahan et al. (2008) and the other (profile-1999) from Chen (2002).

$\S$ Age-depth model of profile in Atahan et al. (2008) was determined by excluding results from old carbon (Wang et al., 2012). Increase in local water level is inferred from the increase in Typha abundance in both profiles. Increase in saline biota (Chenopodiaceae) abundance is seen in profile-1999 by Chen (2002).

『 End of Liangzhu period is inferred from the abrupt decline in abundance of cultural NPPs at $0.6 \mathrm{~m}$ (their Figure 6a in Zong et al., 2012). Increase in local water level is inferred from the increase in abundance of open freshwater NPPs. 

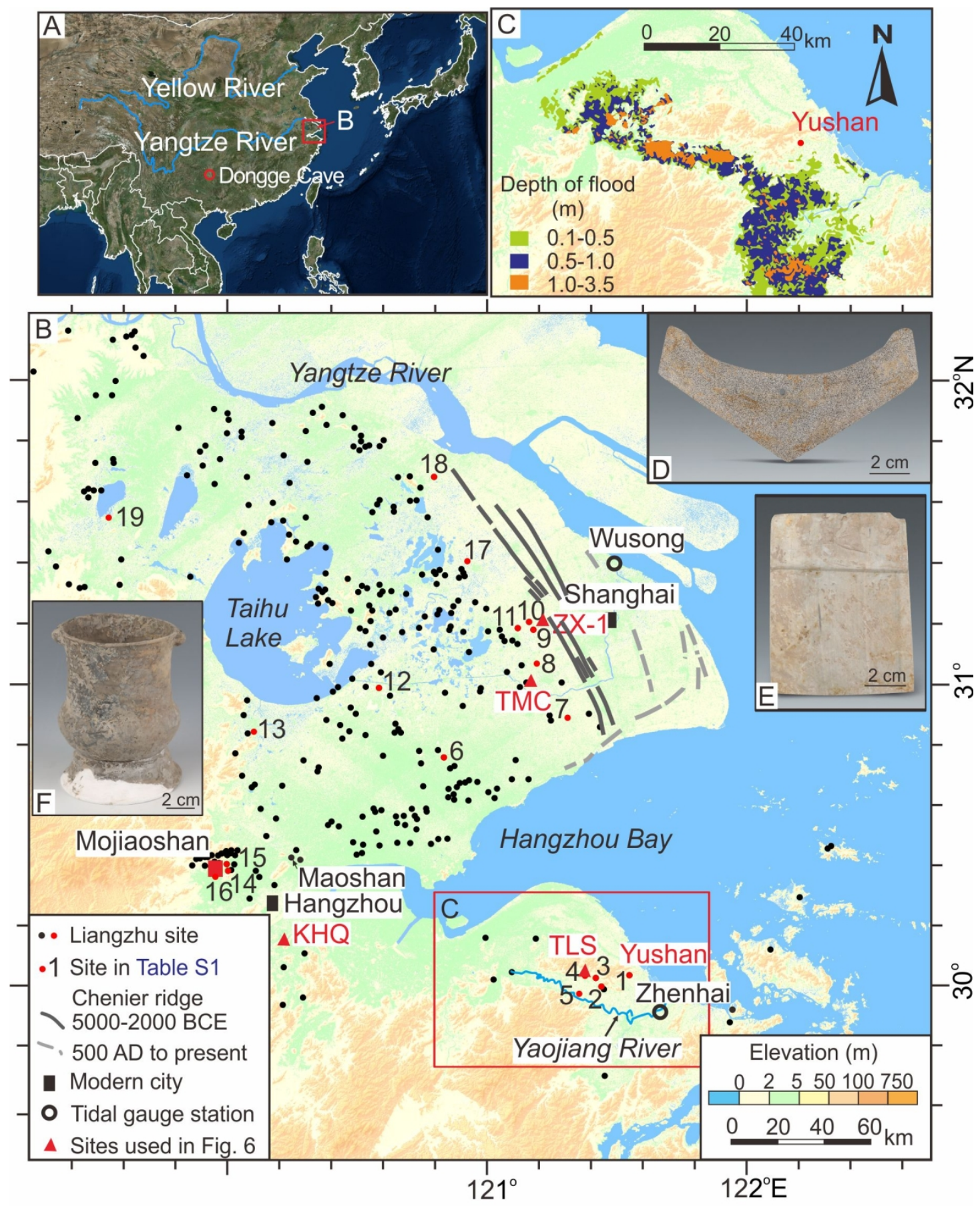

Figure 1 

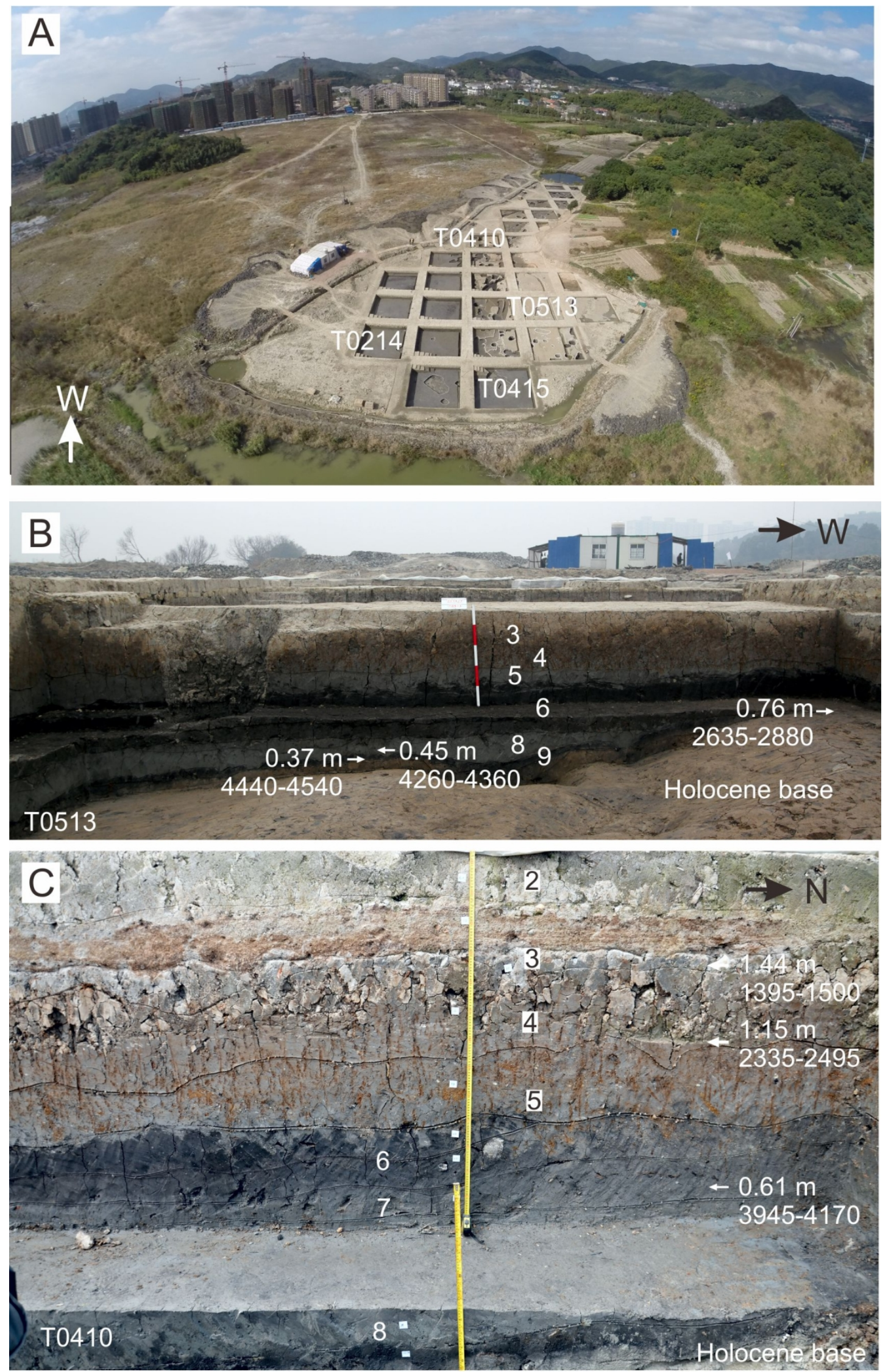

Figure 2 

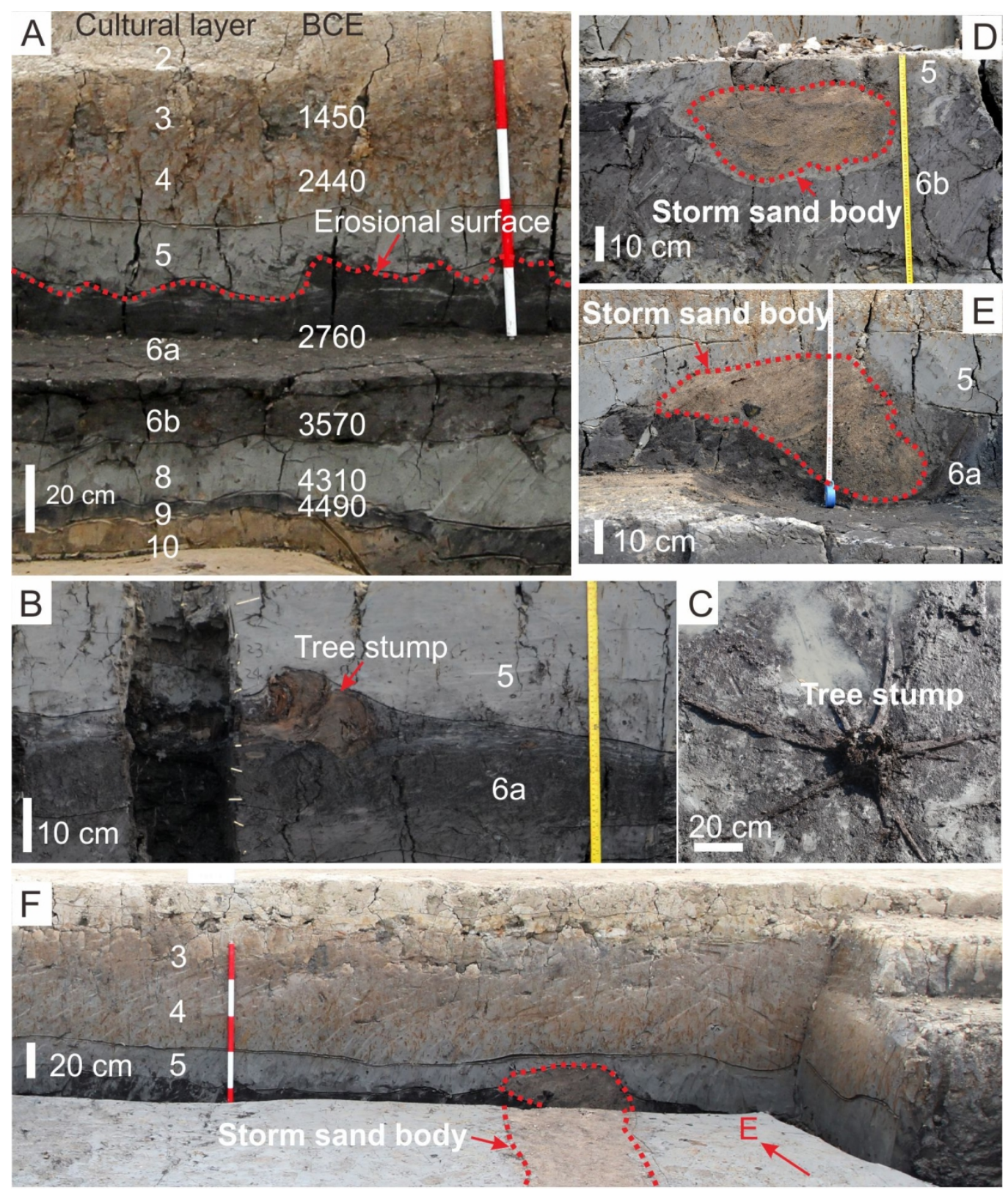

Figure 3 


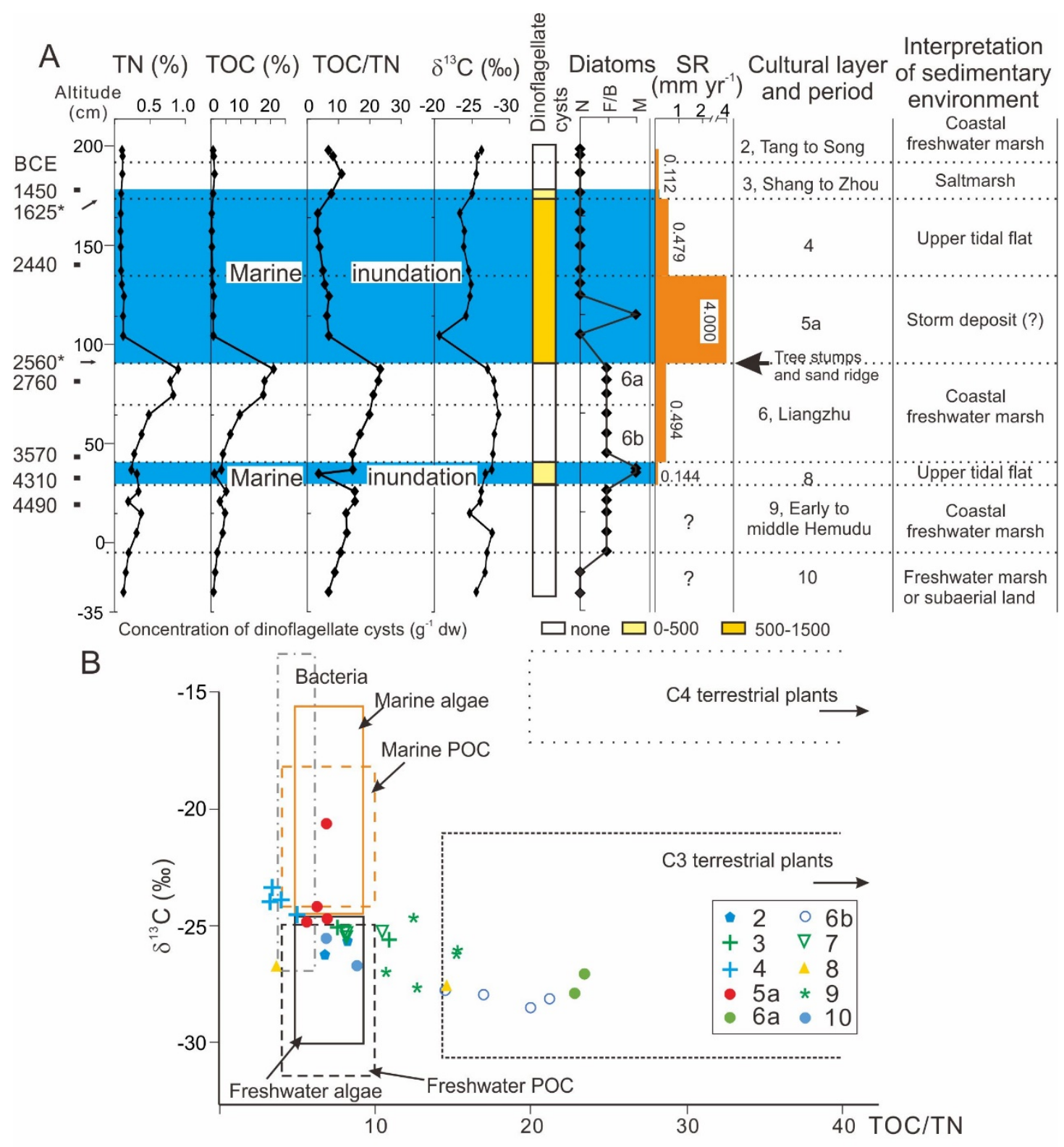

Figure 4 


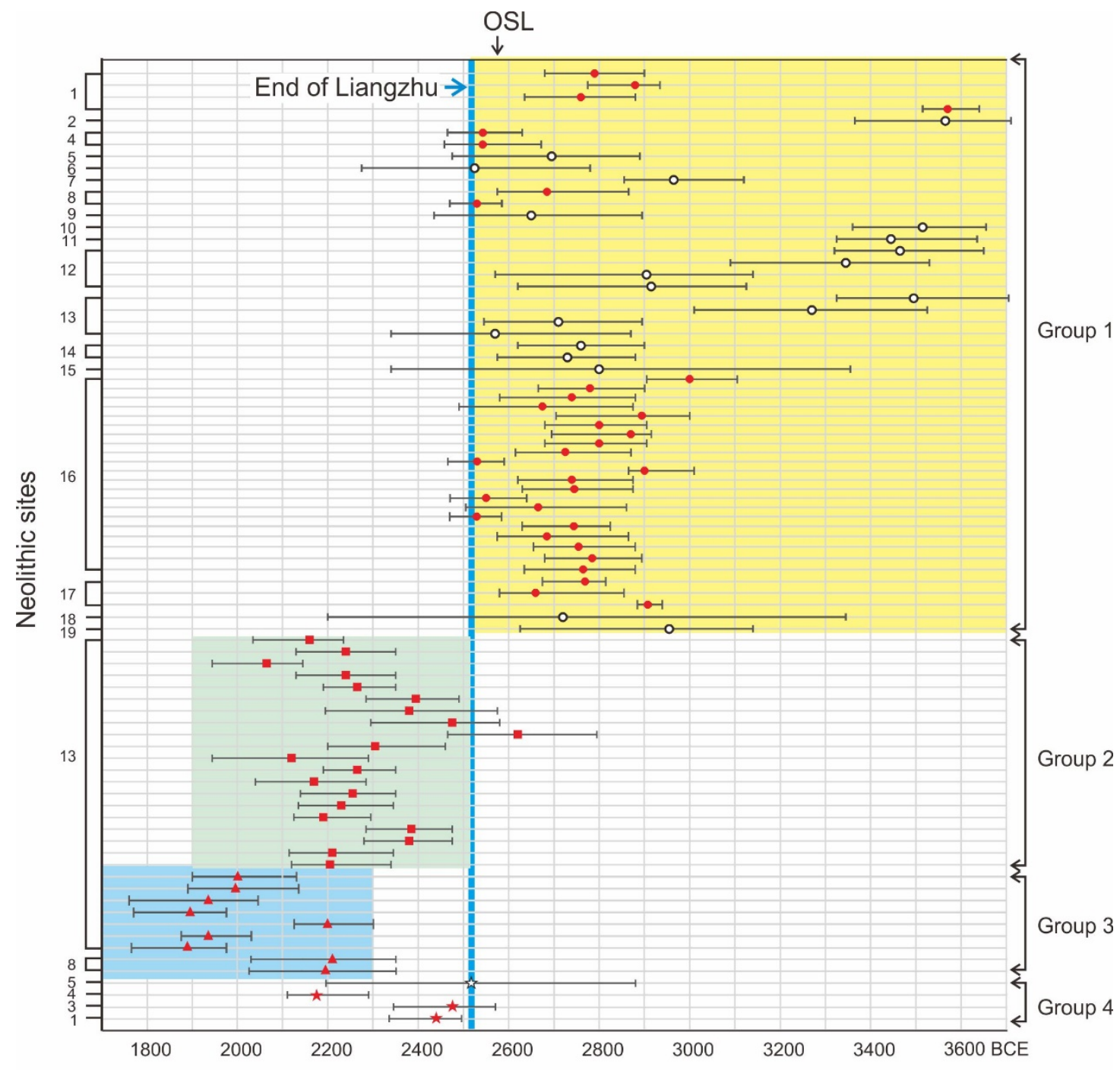

Figure 5 


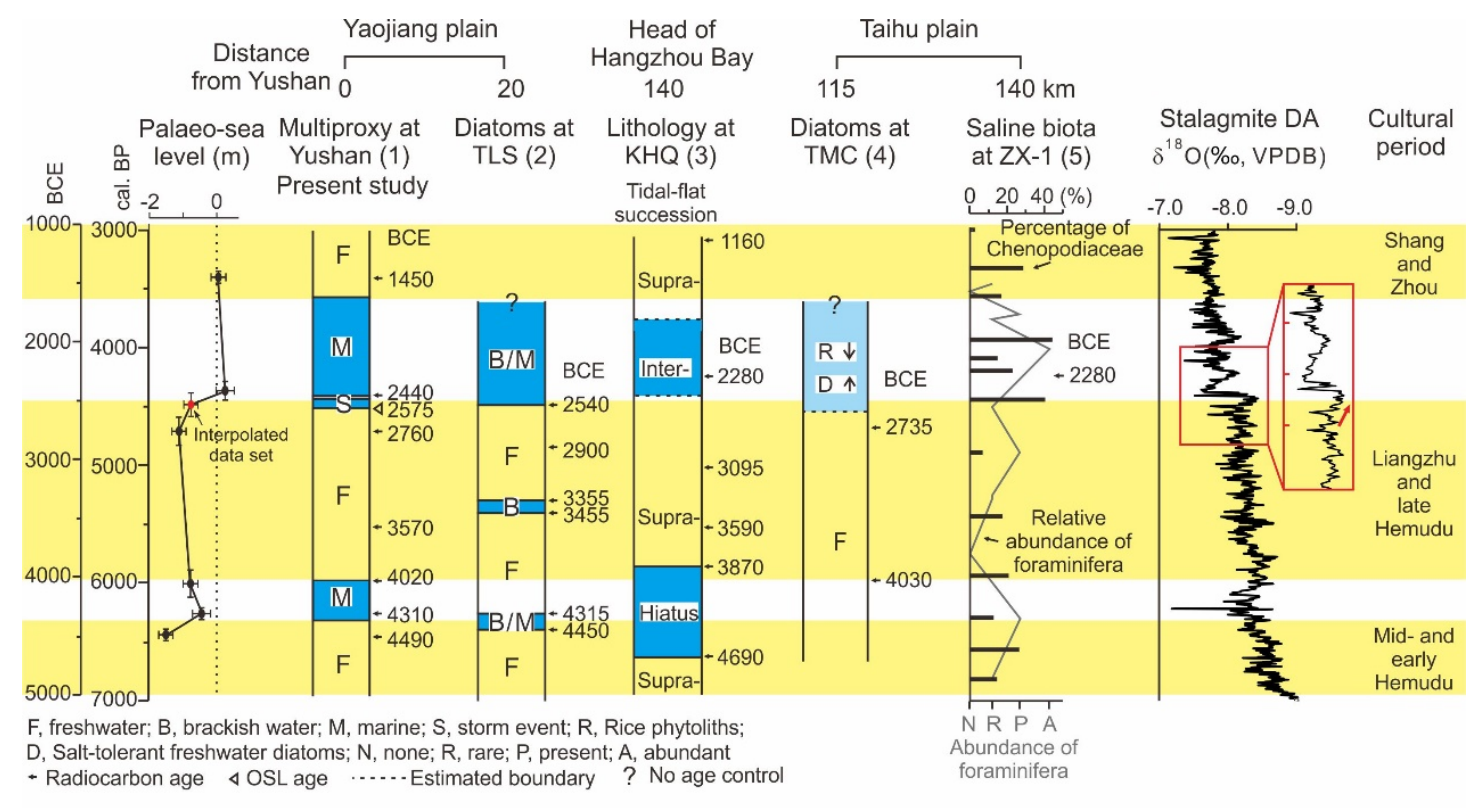

Figure 6 


\section{Mid-Holocene abrupt sea-level rise and human response in the East China coastal plain}

3 Zhanghua Wang ${ }^{1 *}$, David B. Ryves ${ }^{2}$, Shao Lei ${ }^{3}$, Xiaomei Nian ${ }^{1}, \mathrm{Ye} \mathrm{Lv}^{1}$, Liang Tang ${ }^{1}$, Long

4

${ }^{1}$ State Key Laboratory of Estuarine and Coastal Research, ECNU, Shanghai 200062, China.

${ }^{2}$ Centre for Hydrological and Ecosystem Science (CHES), Department of Geography, Loughborough University, Loughborough LE11 3TU, UK.

${ }^{3}$ Ningbo Municipal Institute of Cultural Relics and Archaeology, Ningbo, China.

${ }^{4}$ Shanghai Museum, Shanghai 200003, China.

correspondence to: zhwang@geo.ecnu.edu.cn

\section{This file includes:}

Tables $\mathrm{S} 1$ to $\mathrm{S} 2$

Figs. S1 to S2

References 
Table S1 Neolithic sites (seeing Fig. 1 for their location) with 85 radiocarbon ages during and post the Liangzhu period, which we collected from all publications. Radiocarbon ages were recalibrated with the programme Calib 7.1, using a ${ }^{14} \mathrm{C}$ half-life of 5568 years. This work is to revise the time span of the Liangzhu culture and results show that it ended at 2500 BCE (Fig. 5).

\begin{tabular}{|c|c|c|c|c|c|c|c|c|c|}
\hline $\begin{array}{l}\text { Number in } \\
\text { S.I. Fig. } 1\end{array}$ & Name of site & Cultural layer & Dating material & $\begin{array}{l}\text { Radiocarbon } \\
\text { age (BP) }\end{array}$ & $\begin{array}{l}2 \text { sigma } \\
\text { Calibrated } \\
\text { BCE }\end{array}$ & Prob. & $\begin{array}{l}\text { Median } \\
\text { prob. (cal. } \\
\text { BCE) }\end{array}$ & Data source & Dating method \\
\hline 1 & Yushan & $\begin{array}{l}\text { Natural deposit } \\
\text { above Liangzhu } \\
\text { layer }\end{array}$ & Plant fragment & $3940 \pm 30$ & $2335-2495$ & 0.900 & 2440 & Present study & AMS ${ }^{14} \mathrm{C}$ \\
\hline 3 & Fujiashan & $\begin{array}{l}\text { Natural deposit } \\
\text { above Liangzhu } \\
\text { layer }\end{array}$ & Peaty mud & $3955 \pm 35$ & $2345-2570$ & 1.000 & 2475 & {$[1]$} & AMS ${ }^{14} \mathrm{C}$ \\
\hline 4 & Tianluoshan & $\begin{array}{l}\text { Natural deposit } \\
\text { above the rice field }\end{array}$ & Plant fragment & $3760 \pm 40$ & $2110-2290$ & 0.813 & 2175 & {$[2]$} & AMS ${ }^{14} \mathrm{C}$ \\
\hline 5 & Xiangjiashan & $\begin{array}{l}\text { Disturbed layer } \\
\text { above the Liangzhu }\end{array}$ & Wood & $3990 \pm 130$ & $2195-2880$ & 0.986 & 2515 & {$[3]$} & Radiometric \\
\hline 8 & Guangfulin & Guangfulin & - & $3770 \pm 60$ & $2025-2350$ & 0.947 & 2195 & {$[4]$} & AMS ${ }^{14} \mathrm{C}$ \\
\hline 8 & Guangfulin & Guangfulin & - & $3780 \pm 60$ & $2030-2350$ & 0.925 & 2210 & {$[4]$} & AMS ${ }^{14} \mathrm{C}$ \\
\hline 13 & Qianshanyang & Guangfulin & Wood & $3545 \pm 35$ & $1765-1975$ & 0.994 & 1890 & {$[5]$} & AMS ${ }^{14} \mathrm{C}$ \\
\hline 13 & Qianshanyang & Guangfulin & Charcoal & $3580 \pm 35$ & $1875-2030$ & 0.944 & 1935 & {$[5]$} & AMS ${ }^{14} \mathrm{C}$ \\
\hline 13 & Qianshanyang & Guangfulin & Charcoal & $3775 \pm 35$ & $2125-2300$ & 0.922 & 2200 & {$[5]$} & AMS ${ }^{14} \mathrm{C}$ \\
\hline 13 & Qianshanyang & Guangfulin & Rice & $3550 \pm 35$ & $1770-1975$ & 0.983 & 1895 & {$[5]$} & AMS ${ }^{14} \mathrm{C}$ \\
\hline 13 & Qianshanyang & Guangfulin & Seed & $3580 \pm 55$ & $1760-2045$ & 0.962 & 1935 & {$[5]$} & AMS ${ }^{14} \mathrm{C}$ \\
\hline 13 & Qianshanyang & Guangfulin & Charcoal & $3630 \pm 40$ & $1890-2135$ & 1 & 1995 & {$[5]$} & AMS ${ }^{14} \mathrm{C}$ \\
\hline 13 & Qianshanyang & Guangfulin & Bone & $3635 \pm 35$ & $1900-2130$ & 1 & 2000 & {$[5]$} & AMS ${ }^{14} \mathrm{C}$ \\
\hline
\end{tabular}




\begin{tabular}{|c|c|c|c|c|c|c|c|c|c|}
\hline 13 & Qianshanyang & Qianshanyang & Charcoal & $3780 \pm 40$ & $2120-2340$ & 0.919 & 2205 & {$[5]$} & AMS ${ }^{14} \mathrm{C}$ \\
\hline 13 & Qianshanyang & Qianshanyang & Charcoal & $3780 \pm 45$ & $2115-2345$ & 0.886 & 2210 & {$[5]$} & AMS ${ }^{14} \mathrm{C}$ \\
\hline 13 & Qianshanyang & Qianshanyang & Charred bamboo & $3895 \pm 40$ & $2280-2475$ & 0.965 & 2380 & {$[5]$} & AMS ${ }^{14} \mathrm{C}$ \\
\hline 13 & Qianshanyang & Qianshanyang & Charred bamboo & $3895 \pm 35$ & $2285-2475$ & 0.992 & 2385 & {$[5]$} & AMS ${ }^{14} \mathrm{C}$ \\
\hline 13 & Qianshanyang & Qianshanyang & Charcoal & $3770 \pm 35$ & $2125-2295$ & 0.900 & 2190 & {$[5]$} & AMS ${ }^{14} \mathrm{C}$ \\
\hline 13 & Qianshanyang & Qianshanyang & Charcoal & $3795 \pm 35$ & $2135-2345$ & 0.982 & 2230 & {$[5]$} & AMS ${ }^{14} \mathrm{C}$ \\
\hline 13 & Qianshanyang & Qianshanyang & Wood & $3815 \pm 35$ & $2140-2350$ & 0.934 & 2255 & {$[5]$} & AMS ${ }^{14} \mathrm{C}$ \\
\hline 13 & Qianshanyang & Qianshanyang & Bamboo & $3755 \pm 35$ & $2040-2285$ & 1.000 & 2170 & {$[5]$} & AMS ${ }^{14} \mathrm{C}$ \\
\hline 13 & Qianshanyang & Qianshanyang & Bamboo & $3820 \pm 35$ & $2190-2350$ & 0.828 & 2265 & {$[5]$} & AMS ${ }^{14} \mathrm{C}$ \\
\hline 13 & Qianshanyang & Qianshanyang & Rice & $3720 \pm 60$ & $1945-2290$ & 1.000 & 2120 & {$[5]$} & AMS ${ }^{14} \mathrm{C}$ \\
\hline 13 & Qianshanyang & Qianshanyang & Seed & $3840 \pm 40$ & $2200-2460$ & 0.991 & 2305 & {$[5]$} & AMS ${ }^{14} \mathrm{C}$ \\
\hline 13 & Qianshanyang & Qianshanyang & Seed & $4060 \pm 70$ & $2465-2795$ & 0.845 & 2620 & {$[5]$} & AMS ${ }^{14} \mathrm{C}$ \\
\hline 13 & Qianshanyang & Qianshanyang & Plant fiber & $3960 \pm 50$ & $2295-2580$ & 1.000 & 2475 & {$[5]$} & AMS ${ }^{14} \mathrm{C}$ \\
\hline 13 & Qianshanyang & Qianshanyang & Seed & $3905 \pm 75$ & $2195-2575$ & 0.982 & 2380 & {$[5]$} & AMS ${ }^{14} \mathrm{C}$ \\
\hline 13 & Qianshanyang & Qianshanyang & Bone & $3910 \pm 40$ & $2285-2490$ & 0.980 & 2395 & {$[5]$} & AMS ${ }^{14} \mathrm{C}$ \\
\hline 13 & Qianshanyang & Qianshanyang & Bone & $3820 \pm 35$ & $2190-2350$ & 0.828 & 2265 & {$[5]$} & AMS ${ }^{14} \mathrm{C}$ \\
\hline 13 & Qianshanyang & Qianshanyang & Burned earth & $3800 \pm 40$ & $2130-2350$ & 0.935 & 2240 & {$[5]$} & AMS ${ }^{14} \mathrm{C}$ \\
\hline 13 & Qianshanyang & Qianshanyang & Bamboo & $3675 \pm 40$ & $1945-2145$ & 0.960 & 2065 & {$[5]$} & AMS ${ }^{14} \mathrm{C}$ \\
\hline 13 & Qianshanyang & Qianshanyang & Charcoal & $3800 \pm 40$ & $2130-2350$ & 0.935 & 2240 & {$[5]$} & AMS ${ }^{14} \mathrm{C}$ \\
\hline 13 & Qianshanyang & Qianshanyang & Charcoal & $3750 \pm 40$ & $2035-2235$ & 0.881 & 2160 & {$[5]$} & AMS ${ }^{14} \mathrm{C}$ \\
\hline 1 & Yushan & Liangzhu & Tree stump & $4210 \pm 30$ & $2680-2900$ & 1.000 & 2790 & Present study & AMS ${ }^{14} \mathrm{C}$ \\
\hline 1 & Yushan & Liangzhu & Tree stump & $4240 \pm 30$ & 2705-2910 & 1.000 & 2880 & Present study & AMS ${ }^{14} \mathrm{C}$ \\
\hline 1 & Yushan & Liangzhu & Plant fragments & $4170 \pm 30$ & $2635-2880$ & 1.000 & 2760 & Present study & AMS ${ }^{14} \mathrm{C}$ \\
\hline 1 & Yushan & Liangzhu & Organic sediments & $4770 \pm 30$ & $3515-3640$ & 0.980 & 3570 & Present study & AMS ${ }^{14} \mathrm{C}$ \\
\hline 2 & Cihu & Liangzhu & Wood & $4790 \pm 85$ & $3365-3710$ & 1.000 & 3565 & [6] & Radiometri \\
\hline
\end{tabular}



rice field rice field

Anxi Liangzhu

Bianjiashan Liangzhu

Wood

\section{$3995 \pm 95$}

Charred wood

$4320 \pm 70$

Organic-rich mud

Organic-rich mud

$4110 \pm 30$

2275-2780

$1.000 \quad 2695$

Charred wood

$4730 \pm 80$

2435-2895

$0.973 \quad 2650$

\section{Bamboo}

$4645 \pm 70$

Charcoal

$4685 \pm 90$

Charcoal

$4595 \pm 80$

3325-3635

$1.000 \quad 3515$

$0.910 \quad 3445$

Charcoal

$4280 \pm 125$

Macrocharcoal

$4290 \pm 100$

Charred rice

$4715 \pm 100$

Wood tool

\section{$4565 \pm 90$}

Wood tool

$4130 \pm 85$

Bamboo

$4025 \pm 85$

Charcoal

Charcoal

$4184 \pm 61$

0.9313465

3090-3530 $0.950 \quad 3345$

2570-3140 $0.879 \quad 2905$

2620-3125 $0.911 \quad 2915$

$4200 \pm 40$

$\begin{array}{ll}0.98 & 3000 \\ 0.98 & 2780\end{array}$

Radiometric

Radiometric

Radiometric

AMS ${ }^{14} \mathrm{C}$

AMS ${ }^{14} \mathrm{C}$

Radiometric

Radiometric

Radiometric

Radiometric

Radiometric

Radiometric

Radiometric

Radiometric

Radiometric

Radiometric

Radiometric

Radiometric

Radiometric

Radiometric

AMS ${ }^{14} \mathrm{C}$

AMS ${ }^{14} \mathrm{C}$ 


\begin{tabular}{|c|c|c|c|c|c|c|c|c|c|}
\hline 16 & Bianjiashan & Liangzhu & Plant remains & $4150 \pm 55$ & $2580-2880$ & 1 & 2740 & [16] & AMS ${ }^{14} \mathrm{C}$ \\
\hline 16 & Bianjiashan & Liangzhu & Plant remains & $4095 \pm 70$ & $2490-2875$ & 1 & 2675 & [16] & AMS ${ }^{14} \mathrm{C}$ \\
\hline 16 & Bianjiashan & Liangzhu & Plant remains & $4265 \pm 35$ & $2705-3000$ & 1 & 2895 & [16] & AMS ${ }^{14} \mathrm{C}$ \\
\hline 16 & Bianjiashan & Liangzhu & Plant remains & $4220 \pm 35$ & $2680-2905$ & 1 & 2800 & {$[16]$} & AMS ${ }^{14} \mathrm{C}$ \\
\hline 16 & Bianjiashan & Liangzhu & Plant remains & $4235 \pm 55$ & 2695-2915 & 1 & 2870 & [16] & AMS ${ }^{14} \mathrm{C}$ \\
\hline 16 & Bianjiashan & Liangzhu & Plant remains & $4220 \pm 35$ & $2680-2905$ & 1 & 2800 & [16] & AMS ${ }^{14} \mathrm{C}$ \\
\hline 16 & Bianjiashan & Liangzhu & Plant remains & $4130 \pm 40$ & $2615-2870$ & 0.93 & 2725 & [16] & AMS ${ }^{14} \mathrm{C}$ \\
\hline 16 & Bianjiashan & Liangzhu & Plant remains & $4010 \pm 35$ & $2465-2590$ & 0.96 & 2530 & [16] & AMS ${ }^{14} \mathrm{C}$ \\
\hline 16 & Bianjiashan & Liangzhu & Plant remains & $4275 \pm 40$ & $2865-3010$ & 0.92 & 2900 & [16] & AMS ${ }^{14} \mathrm{C}$ \\
\hline 16 & Bianjiashan & Liangzhu & Plant remains & $4145 \pm 35$ & $2620-2875$ & 1 & 2740 & {$[16]$} & AMS ${ }^{14} \mathrm{C}$ \\
\hline 16 & Bianjiashan & Liangzhu & Ash & $4150 \pm 30$ & $2630-2875$ & 1 & 2745 & [16] & AMS ${ }^{14} \mathrm{C}$ \\
\hline 16 & Bianjiashan & Liangzhu & Ash & $4030 \pm 40$ & $2470-2640$ & 0.95 & 2550 & {$[16]$} & AMS ${ }^{14} \mathrm{C}$ \\
\hline 16 & Bianjiashan & Liangzhu & Fabric & $4100 \pm 30$ & $2505-2860$ & 1 & 2665 & [16] & AMS ${ }^{14} \mathrm{C}$ \\
\hline 16 & Bianjiashan & Liangzhu & $\begin{array}{l}\text { HyPy residue of } \\
\text { charcoal }^{*}\end{array}$ & $4020 \pm 30$ & $2470-2585$ & 0.959 & 2530 & [17] & AMS ${ }^{14} \mathrm{C}$ \\
\hline 16 & Bianjiashan & Liangzhu & $\begin{array}{l}\text { HyPy residue of } \\
\text { charcoal }\end{array}$ & $4150 \pm 30$ & $2630-2825$ & 0.804 & 2745 & [17] & AMS ${ }^{14} \mathrm{C}$ \\
\hline 16 & Bianjiashan & Liangzhu & $\begin{array}{l}\text { HyPy residue of } \\
\text { charcoal }\end{array}$ & $4110 \pm 30$ & $2575-2865$ & 1.000 & 2685 & [17] & AMS ${ }^{14} \mathrm{C}$ \\
\hline 16 & Bianjiashan & Liangzhu & $\begin{array}{l}\text { HyPy residue of } \\
\text { charcoal }\end{array}$ & $4160 \pm 30$ & $2655-2880$ & 0.951 & 2755 & [17] & AMS ${ }^{14} \mathrm{C}$ \\
\hline 16 & Bianjiashan & Liangzhu & Wood & $4200 \pm 30$ & $2680-2895$ & 1 & 2785 & [17] & AMS ${ }^{14} \mathrm{C}$ \\
\hline 16 & Bianjiashan & Liangzhu & Wood & $4170 \pm 30$ & $2635-2880$ & 1 & 2765 & [17] & AMS ${ }^{14} \mathrm{C}$ \\
\hline 17 & Zhumucun & Liangzhu & Plant & $4170 \pm 20$ & $2675-2815$ & 0.805 & 2770 & [18] & AMS ${ }^{14} \mathrm{C}$ \\
\hline 17 & Zhumucun & Liangzhu & Charred rice grain & $4105 \pm 20$ & $2580-2855$ & 1.000 & 2660 & [18] & AMS ${ }^{14} \mathrm{C}$ \\
\hline 17 & Zhumucun & River channel $^{\dagger}$ & Charred rice grain & $3885 \pm 25$ & $2295-2465$ & 1.000 & 2385 & [18] & AMS ${ }^{14} \mathrm{C}$ \\
\hline
\end{tabular}




\begin{tabular}{llllllllll}
17 & Zhumucun & Liangzhu & Charred rice grain & $4305 \pm 25$ & $2885-2940$ & 0.925 & 2910 & {$[18]$} & AMS ${ }^{14} \mathrm{C}$ \\
18 & Sidun & Liangzhu & Charcoal & $4150 \pm 205$ & $2200-3345$ & 0.996 & 2720 & {$[19$} & Radiometric \\
19 & Yangzhu & Liangzhu & Wood & $4310 \pm 110$ & $2625-3140$ & 0.849 & 2955 & {$[20]$} & Radiometric \\
\hline
\end{tabular}

$40 \quad{ }^{*} \mathrm{HyPy}$ (catalytic hydropyrolysis) residue is the contaminant-free black carbon fraction of charcoal and thus can produce an accurate ${ }^{14} \mathrm{C}$ age.

$41 \dagger$ This sample was collected from river channel which could deposit younger sediments, thus it was excluded in Fig. 5. 
Table S2 Radiocarbon ages collected from TLS (Tianluoshan), KHQ (Kuahuqiao), TMC (Tangmiaocun) and ZX-1 and their calibration using the Calib 7.1 program. The mollusk shell was calibrated using the Marine13 calibration curve and the regional reservoir correction $(\Delta \mathrm{R})$ value of $-1 \pm 143$ was averaged from samples from Tsingtao, southwest coast of Korea and northwest coast of Taiwan ${ }^{24-26}$.

\begin{tabular}{lllllll}
\hline Name of site & $\begin{array}{l}\text { Dating } \\
\text { material }\end{array}$ & $\begin{array}{l}\text { Radiocarbon } \\
\text { age (BP) }\end{array}$ & $\begin{array}{l}\text { 2 sigma } \\
\text { Calibrated } \\
\text { BCE }\end{array}$ & $\begin{array}{l}\text { Prob. } \\
\text { TLS }\end{array}$ & $\begin{array}{l}\text { Median } \\
\text { prob. (cal. } \\
\text { BCE) }\end{array}$ & $\begin{array}{l}\text { Data } \\
\text { source }\end{array}$ \\
& Seeds & $4020 \pm 40$ & $2465-2635$ & 0.98 & 2540 & {$[7]$} \\
& Seeds & $4275 \pm 40$ & $2865-3010$ & 0.92 & 2900 & {$[7]$} \\
& Seeds & $4585 \pm 35$ & $3115-3500$ & 1 & 3355 & {$[7]$} \\
& Seeds & $4660 \pm 40$ & $3360-3525$ & 0.96 & 3455 & {$[7]$} \\
& Seeds & $5465 \pm 45$ & $4235-4375$ & 0.96 & 4315 & {$[7]$} \\
KHQ & Seeds & $5620 \pm 35$ & $4360-4520$ & 1 & 4450 & {$[7]$} \\
& Not given & $2950 \pm 100$ & $915-1415$ & 1 & 1160 & {$[21]$} \\
& Not given & $3825 \pm 100$ & $2015-2500$ & 0.97 & 2280 & {$[21]$} \\
& Not given & $4410 \pm 120$ & $2860-3375$ & 0.96 & 3095 & {$[21]$} \\
& Not given & $4820 \pm 150$ & $3325-3965$ & 0.97 & 3590 & {$[21]$} \\
& Not given & $5070 \pm 150$ & $3630-4245$ & 0.96 & 3870 & {$[21]$} \\
TMC & Not given & $5820 \pm 170$ & $4335-5075$ & 0.99 & 4690 & {$[21]$} \\
& Pollen & $4140 \pm 40$ & $2615-2875$ & 0.97 & 2735 & {$[22]$} \\
& residue & & & & & \\
& Pollen & $5230 \pm 40$ & $3965-4225$ & 1 & 4030 & {$[22]$} \\
& residue & & & & & \\
& Mollusc & $4160 \pm 40$ & $1870-2695$ & 1 & 2280 & {$[23]$} \\
& shell & & & & & \\
\hline
\end{tabular}

51 


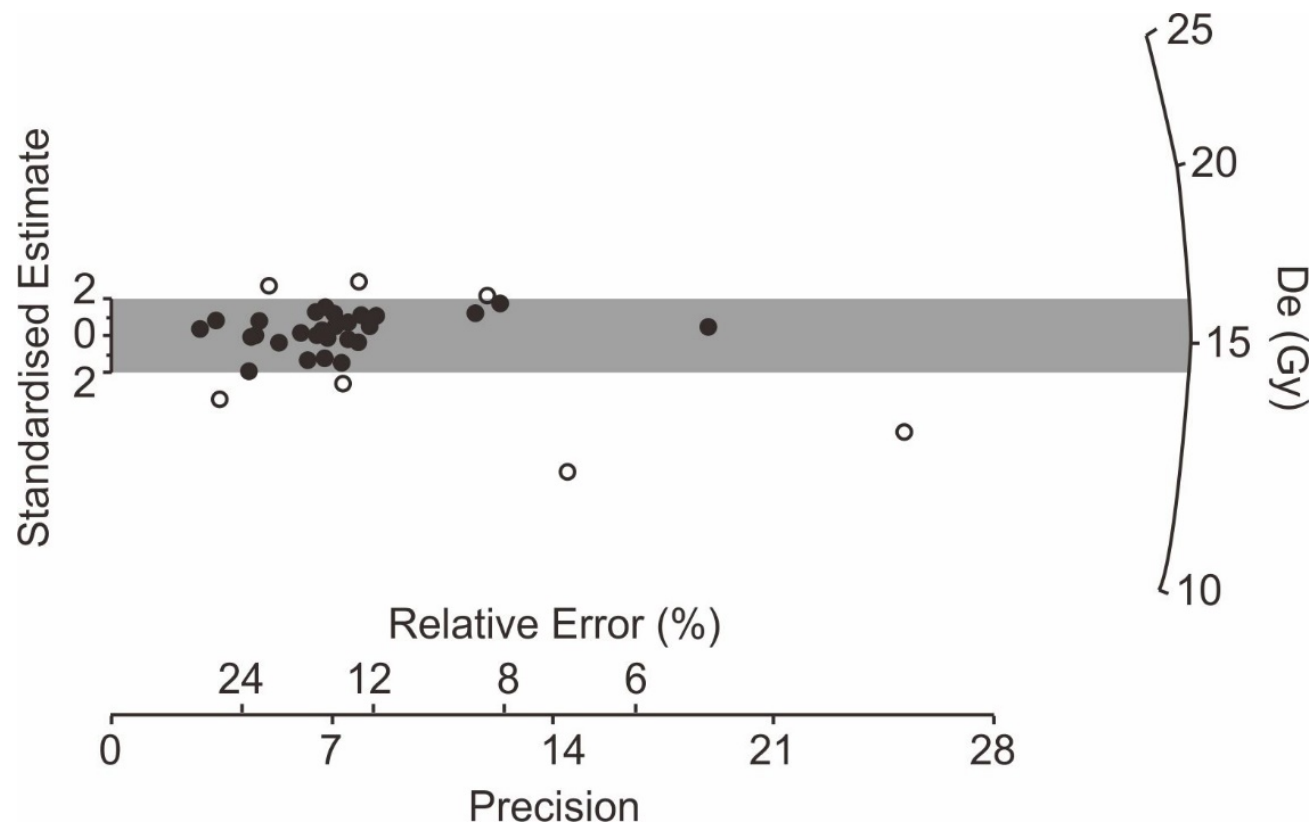

61

Figure S1 Radial plot of measured doses (Central Age Model, CAM) for single grains of quartz

62 from Yushan site. The open symbols relate to De values outside the $\pm 2 \delta$ range.

63

64

65

66

67

68

69

70

71

72

73

74

75 


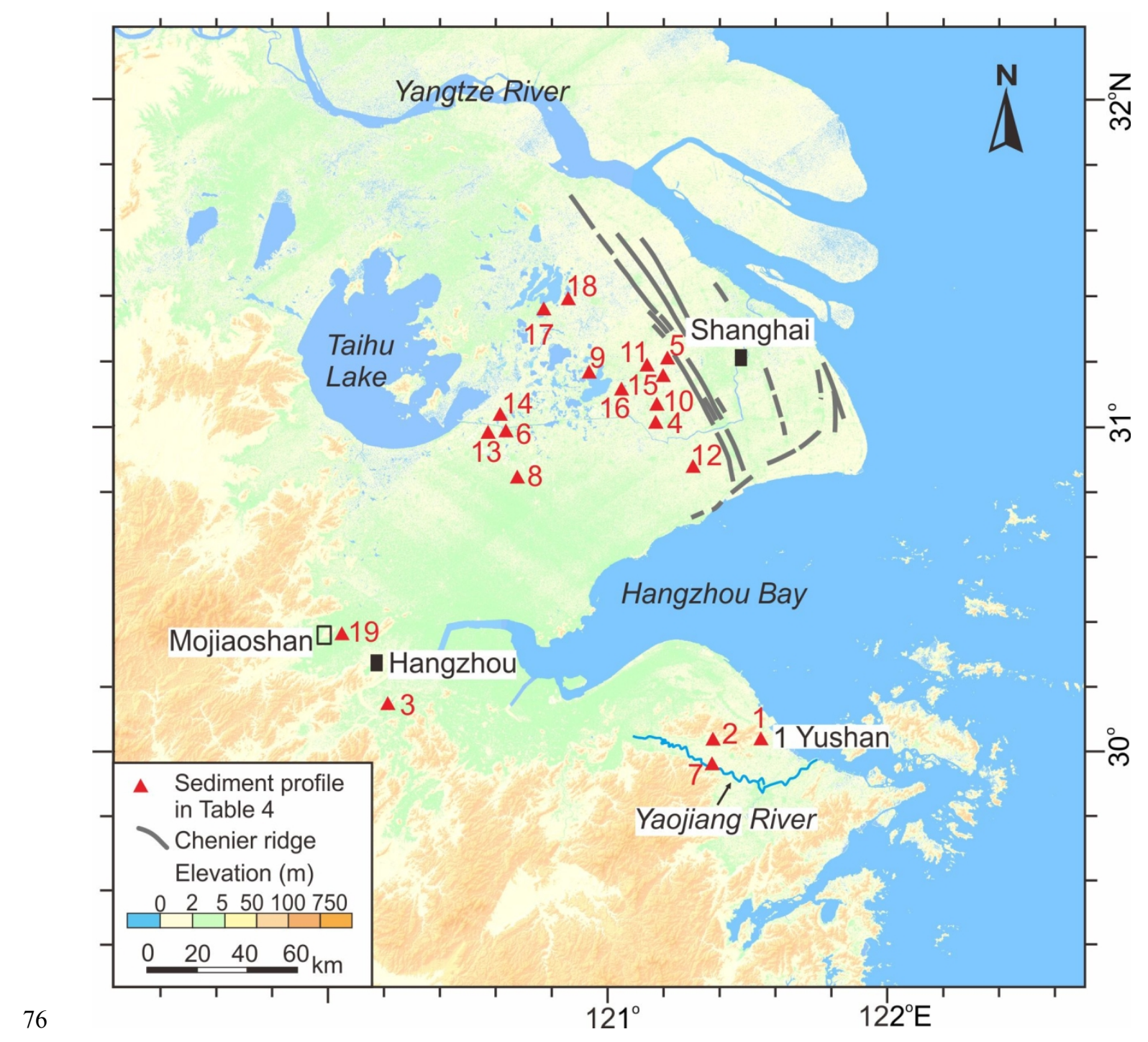

Figure S2 Distribution of sediment profiles with high-resolution radiocarbon dates (Tables 4,

S2). The map is generated by software ArcGis 10.1 (www.esrichina.com.cn) using the data

set of topography provided by International Scientific \& Technical Data Mirror Site,

(http://www.gscloud.cn). 


\section{References}

1. Zheng, Y., Sun, G., Qin, L., Li, C., Wu, X., Chen, X., 2009. Rice fields and modes of rice cultivation between 5000 and 2500 BC in east China. Journal of Archaeological Science $36,2609-2616$

2. Ningbo Municipal Institute of Cultural Relics and Archaeology, 2013. FU JIA SHAN--The Excavated Report on the Neolithic Site. Science Press, Beijing (in Chinese).

3. Institute of Archaeology, Chinese Academy of Social Science, 1996. Radiocarbon reports (23). KAO GU (7), 66-70 (in Chinese).

4. Shanghai Museum, 2002. The excavated report on the Neolithic site GUANG FU LIN, Songjiang, Shanghai during 1999-2000. KAO GU (10), 31-48 (in Chinese).

5. Zhejiang Provincial Institute of Cultural Relics and Archaeology, Huzhou Meseum, 2014. Qianshanyang: a report on the third and fourth excavations of the site. WEN WU Press, Beijing (in Chinese).

6. Liu, J., 2006. The Hemudu Culture. WEN WU Press, Beijing (in Chinese).

7. Zheng, Y., Sun, G., Chen, X., 2012. Response of rice cultivation to fluctuating sea level during the Mid-Holocene. Chinese Science Bulletin 57, 370-378.

8. Jiaxing Museum, 1974. The black pottery discovered at Quemuqiao, Jiaxing. KAO GU (4), 249-250 (in Chinese).

9. Institute of Archaeology \& Chinese Academy of Social Science, 1992. Radiocarbon database in Chinese Archaeology (1965-1991). WEN WU Press, Beijing (in Chinese).

10. Wang, Z., Chen, J., Zhan, Q., Zhuang, C., Wu, X., Wang, X., 2014. Holocene paleo- 
environmental change and its relationship with the Neolithic culture at Guangfulin site. Proceedings on the excavation at Guang Fu Lin, ed. Shanghai Museum (Shanghai Gu Ji Press, Shanghai), pp325-335 (in Chinese).

11. Shanghai Cultural Relics Committee, 2001. FU QUAN SHAN-The excavated report on the Neolithic Site. WEN WU Press, Beijing (in Chinese).

12. Department of Archaeology, Beijing University, 1996. Radiocarbon reports (10). WEN WU (6), 91-95 (in Chinese).

13. Suzhou Museum \& Wujiang cultural relics committee, 1990. The report of first and second excavation on the Longnan Neolithic site, Wujiang, Jiangsu. WEN WU (7), 1-27 (in Chinese).

14. Institute of Archaeology, Chinese Academy of Social Science, 1977. Radiocarbon reports. KAO GU (3), 200-204 (in Chinese).

15. Institute of Archaeology, Chinese Academy of Social Science, 1999. Radiocarbon reports (25). KAO GU (7), 80-83 (in Chinese).

16. Zhejiang Provincial Institute of Cultural Relics and Archaeology, 2014. Bianjiashan Site, the Sixth Part Report of Liangzhu Culture Sites. WEN WU Press, Beijing (in Chinese).

17. Zhang, X., Huang, D., Deng, H., Snape, C., Meredit,h W., Zhao, Y., Du, Y., Chen, X., Sun, Y., 2015. Radiocarbon dating of charcoal from the Bianjiashan site in Hangzhou: New evidence for the lower age limit of the Liangzhu Culture. Quaternary Geochronology $30,9-17$.

18. Qiu, Z., Shang, X., Ferguson, D.K., Jiang, H., 2016. Archaeobotanical analysis of diverse plant food resources and palaeovegetation at the Zhumucun site, a late Neolithic settlement 
of the Liangzhu Culture in east China. Quaternary International 426, 75-85.

131

19. Nanjing Museum, 1984. The excavated report on the Sidun Neolithic site, Wujing, Changzhou, Jiangsu in 1982. KAO GU (2), 109-129 (in Chinese).

20. Wu, J., 1988. Distribution of prehistory sites and the environmental change on the Yangtze Delta plain. DONG NAN WEN HUA (6), 16-36 (in Chinese).

21. ZPICRA, 2004. KUA HU QIAO-Archaeological Report of Puyang River Valley I. WEN WU Press, Beijing (in Chinese).

22. Zong, Y., Innes, J.B., Wang, Z., Chen, Z., 2011. Mid-Holocene coastal hydrology and salinity changes in the east Taihu area of the lower Yangtze wetlands, China. Quaternary Research 76, 69-82.

23. Chen, Z., Wang, Z., Schneiderman, J., Cai, Y., 2005. Holocene climate fluctuations on millennium scale in the Yangtze delta of eastern China: implications and response. The Holocene 15, 917-926.

24. Southon, J., Kashgarian, M., Fontugne, M., Metivier, B., Yim, W.W.-S., 2002. Marine reservoir corrections for the Indian Ocean and Southeast Asia. Radiocarbon 44, 167-180.

25. Kong, G.S., Lee, C.W., 2005. Marine reservoir corrections $(\Delta R)$ for southern coastal waters of Korea. The Sea, Journal of the Korean Society of Oceanography 10(2), 124128.

26. Yoneda, M., Uno, H., Shibata, Y., Suzuki, R., Kumamoto, Y., Yoshida, K., Sasaki, T., Suzuki, A., Kawahata, H., 2007. Radiocarbon marine reservoir ages in the western Pacific estimated by pre-bomb molluscan shells. Nuclear Instruments and Methods in Physics Research B 259, 432-437. 